\title{
Taxonomic revision of the spider family Penestomidae (Araneae, Entelegynae)
}

\author{
JEREMY A. MILLER ${ }^{1,2,4,}$, CHARLES E. GRISWOLD ${ }^{1,6} \&$ CHARLES R. HADDAD ${ }^{3,7}$ \\ ${ }^{1}$ Department of Entomology, California Academy of Sciences, 55 Music Concourse Drive, Golden Gate Park, San \\ Francisco, CA 94118, USA \\ ${ }^{2}$ Current address: Department of Terrestrial Zoology, Netherlands Centre for Biodiversity Naturalis, Postbus 95172300 \\ RA Leiden, The Netherlands \\ ${ }^{3}$ Department of Zoology \& Entomology, University of the Free State, P. O. Box 339, Bloemfontein 9300, South Africa \\ ${ }^{4}$ Corresponding author: E-mail: jeremy.miller@ncbnaturalis.nl \\ ${ }^{5}$ http://zoobank.org/urn:lsid:zoobank.org:author:3B8D159E-8574-4D10-8C2D-716487D5B4D8 \\ ${ }^{6} \mathrm{http}: / /$ zoobank.org/urn:1sid:zoobank.org:author:0676B242-E441-4715-BF20-1237BC953B62 \\ ${ }^{7}$ http://zoobank.org/urn:Isid:zoobank.org:author:417ED537-9B99-48BD-B2AB-CC27E762C850
}

\section{Table of contents}

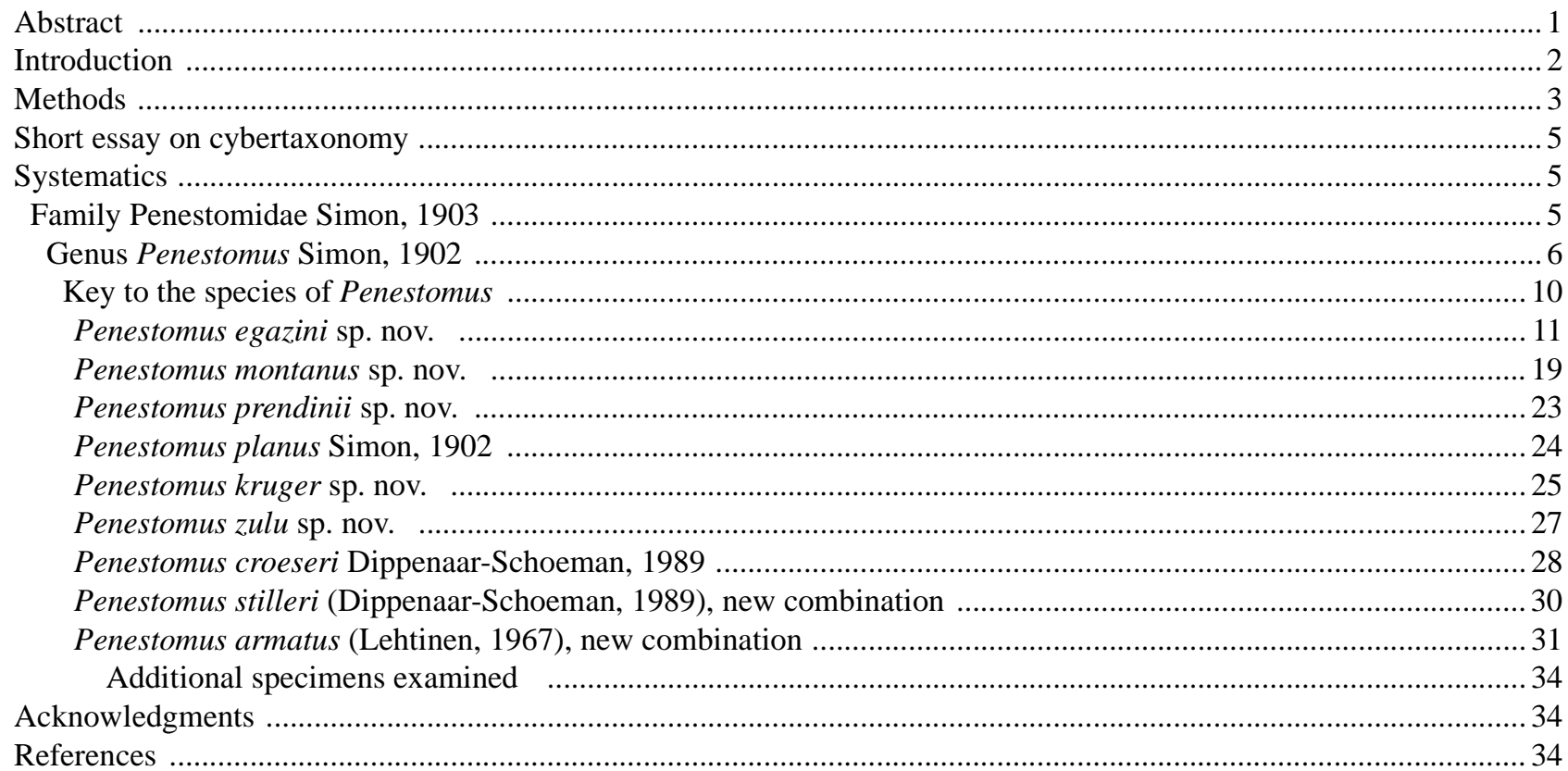

\begin{abstract}
Conflicting character evidence and a scarcity of male specimens has historically made placement of the spider subfamily Penestominae Simon problematic. The Penestominae was recently removed from the family Eresidae and promoted to family rank based on the results of a molecular phylogenetic study; a complementary taxonomic revision of the Penestomidae is presented here. Penestomidae contains a single genus, Penestomus Simon, 1902. The genus Wajane Lehtinen, 1967 was previously included in the Penestominae, and distinguished from Penestomus based on the lack of a cribellum. Wajane is, in fact, cribellate, and is here synonymized with Penestomus New synonymy. Nine Penestomus species are recognized: four species are redescribed (P. planus Simon, 1902, P. croeseri Dippenaar-Schoeman, $1989, P$. stilleri (Dippenaar-Schoeman, 1989), new combination, and $P$. armatus (Lehtinen, 1967)) new combination, and five species are newly described ( $P$. egazini sp. nov., P. kruger sp. nov., P. montanus sp. nov., $P$. prendinii sp. nov., and $P$. zulu sp. nov.). Male specimens are rare in collections; only P. egazini, P. montanus, and P. armatus are known from
\end{abstract}


males, and only P. armatus is unknown from females. A dichotomous key to the species is provided. Data elements in this work have been disseminated across multiple electronic venues, including images on Morphbank, distribution data exposed through GBIF and explorable using Google Earth, new nomenclatural acts registered with ZooBank, and species pages on the Encyclopedia of Life. Where available, species descriptions include links to molecular sequence data on GenBank.

Key words: cribellum, cybertaxonomy, Eresidae, Penestomus, South Africa, Wajane, Zodariidae

Publication LSID: http://zoobank.org/urn:1sid:zoobank.org:pub:8F657D94-8DD3-4184-BB90-A43C3268DF42

\section{Introduction}

Penestomidae Simon are small (ca. 4-6 mm long) dorsoventrally flattened, short-legged spiders endemic to South Africa and the enclave of Lesotho. Until recently, they were considered a subfamily of Eresidae C. L. Koch (the Penestominae) containing two genera, Penestomus Simon and Wajane Lehtinen. They are relatively rare in collections and little is known of their biology. Previously, only eight adult specimens (four species) were documented in the literature. This work brings the number of adult specimens to 60 (nine species); of these, only four are male (three species).

Their rarity, limited distribution, and an unusual combination of morphological characteristics have made this group one of the most enigmatic lineages in spider systematics. The first penestomine was described from the female only and placed in the family Eresidae. Even in the original description (Simon 1902), it was noted that these spiders were atypical eresids. Nevertheless, there are several morphological characters that appear to support placement within Eresidae including the presence of a clypeal hood (Fig. 1C; compare to Griswold et al. 2005, fig. 129A), specialized white setae, a subrectangular carapace, and stout legs (Fig. 1B). In addition, penestomines lack tarsal trichobothria; eresids and most other spiders outside of the RTA clade (see below) symplesiomorphically lack tarsal trichobothria (Griswold et al. 1999; Griswold et al. 2005).

Ambiguity about the proper placement of penestomines deepened with the description of the first male (Lehtinen 1967) because the male pedipalps do not resemble those of other eresids and feature a strong retrolateral tibial apophysis (RTA). The RTA defines a major clade of spiders (more than half of spider diversity) exclusive of Eresidae (Coddington \& Levi 1991; Griswold et al. 2005). Penestomine males also have a median apophysis (MA). This pedipalpal sclerite has a more complicated evolutionary history than the RTA, but it is common in RTA clade taxa and orbicularians (orb-web building spiders and their descendents), and absent from other eresids (Coddington 1990; Griswold et al. 1998; Griswold et al. 1999; Griswold et al. 2005).

The conflicting morphological data suggest one of two scenarios: either the RTA and MA evolved independently in penestomine eresids and RTA-clade spiders, or penestomines are misplaced in Eresidae and belong instead within the RTA-clade. To resolve this conflicting character evidence and to test the phylogenetic position of the Penestominae, Miller et al. (2010) assembled a matrix of molecular sequence data (fragments from four genes, ca. 3500 aligned nucleotide positions). Taxon sampling emphasized both Eresidae and the RTA clade. Phylogenetic analysis indicated that penestomines belong within the RTA clade close to Zodariidae. This relationship has significantly better support (Shimodaira \& Hasegawa 1999) than the most likely tree constrained to contain a monophyletic Eresidae including Penestominae. Based on this analysis, Miller et al. (2010) removed Penestominae from Eresidae and promoted it to family rank. Penestomidae joins Chummidae Jocqué to become the second spider family endemic to South Africa (including the enclave of Lesotho). The spider fauna of southern Africa is quite distinct and includes several endemic lineages; selected examples are listed in Table 1. 
TABLE 1. Selected examples of spider genera and families endemic to southern Africa (south of Kunene and Limpopo Rivers including Lesotho, Namibia and South Africa), and references to relevant taxonomic studies. Taxa indicated with an asterisk are endemic to South Africa.

\begin{tabular}{|c|c|c|}
\hline Family & Genera & References \\
\hline Amaurobiidae & $\begin{array}{l}\text { Chresiona Simon*, Obatala Lehtinen*, Pseudauximus } \\
\text { Simon* }\end{array}$ & Platnick 2010; Miller et al. 2010 \\
\hline Ammoxenidae & Ammoxenus Simon, Rastellus Platnick \& Griffin & $\begin{array}{l}\text { Dippenaar \& Meyer 1980; Platnick \& } \\
\text { Griffin } 1990\end{array}$ \\
\hline Chummidae* & Chumma Jocqué* & Jocqué 2001 \\
\hline Corinnidae & $\begin{array}{l}\text { Austrophaea Lawrence*, Fuchiba Haddad \& Lyle, } \\
\text { Fuchibotulus Haddad \& Lyle, Lessertina Lawrence*, } \\
\text { Poachelas Haddad \& Lyle, Pronophaea Simon*, } \\
\text { Spinotrachelas Haddad*, Vendaphaea Haddad* }\end{array}$ & $\begin{array}{l}\text { Bosselaers \& Jocqué 2000; Haddad } \\
\text { 2006, 2007, 2009; Haddad \& } \\
\text { Bosselaers 2010; Haddad \& Lyle } \\
2008\end{array}$ \\
\hline Cyatholipidae & $\begin{array}{l}\text { Cyatholipus Simon*, Ilisoa Griswold*, Ubacisi } \\
\text { Griswold* }\end{array}$ & Griswold 2001 \\
\hline Cyrtaucheniidae & Homostola Simon* & Platnick 2010 \\
\hline Eresidae & Paradonea Lawrence, Seothyra Purcell & Platnick 2010 \\
\hline Gallieniellidae & Austrachelas Lawrence*, Drassodella Hewitt* & Haddad et al. 2009 \\
\hline Idiopidae & Ctenolophus Purcell, Segregara Tucker & Platnick 2010 \\
\hline Microstigmatidae & Microstigmata Strand* & Griswold 1991a \\
\hline Nemesiidae & Lepthercus Purcell*, Pionothele Purcell* & Platnick 2010 \\
\hline Oonopidae & $\begin{array}{l}\text { Australoonops Hewitt*, Calculus Purcell*, } \\
\text { Pseudoscaphiella Simon* }\end{array}$ & Platnick 2010 \\
\hline Orsolobidae & Azanialobus Griswold \& Platnick* & Griswold \& Platnick 1987 \\
\hline Phyxelididae & $\begin{array}{l}\text { Lamaika Griswold*, Malaika Lehtinen*, Matundua } \\
\text { Lehtinen*, Namaquarachne Griswold*, Pongolania } \\
\text { Griswold*, Themacrys Simon*, Vidole Lehtinen* }\end{array}$ & Griswold 1990 \\
\hline Prodidomidae & $\begin{array}{l}\text { Austrodomus Lawrence*, Eleleis Simon*, Purcelliana } \\
\text { Cooke* }\end{array}$ & Platnick 2010 \\
\hline Theraphosidae & $\begin{array}{l}\text { Brachionopus Pocock*, Harpactira Ausserer, } \\
\text { Trichognathella Gallon* }\end{array}$ & $\begin{array}{l}\text { Dippenaar-Schoeman 2002; Gallon } \\
2002\end{array}$ \\
\hline Zodariidae & $\begin{array}{l}\text { Caesetius Simon, Cicynethus Simon, Heradida } \\
\text { Simon, Procydrela Jocqué*, Psammoduon Jocqué, } \\
\text { Psammorygma Jocqué, Rotundrela Jocqué*, } \\
\text { Thaumastochilus Simon }\end{array}$ & Jocqué 1991, 1999, 2009 \\
\hline Zoropsidae & $\begin{array}{l}\text { Griswoldia Dippenaar-Schoeman \& Jocqué*, } \\
\text { Phanotea Simon* }\end{array}$ & Griswold 1991b; Griswold 1994 \\
\hline
\end{tabular}

\section{Methods}

Measurements (in millimeters) were taken using a reticule in a Leica MZ12.5 stereomicroscope; carapace length and width were taken in dorsal view, carapace height (from margin to midline) was taken in lateral view; leg articles were measured in lateral view along dorsal margin. Macrosetae are reported for the dorsal 
(d), prolateral (p), retrolateral (r), and ventral (v) surfaces of the legs and are listed from proximal to distal ends of each segment. Measurements are given based on one specimen of each sex, where available; coloration and counts of macrosetae are usually based on multiple specimens to mitigate artifacts due to specimen preservation.

Digital photographs were taken with a Nikon DXM 1200 digital camera mounted on a Leica MZ16A stereomicroscope. Line drawings were traced from digital photographs and rendered in Adobe Photoshop (version 6.0). Photographs of the epigynum in dorsal view were taken with the specimen cleared in methyl salicylate (Holm 1979) and slide mounted (Coddington 1983). Illustrations of male genitalia were sketched using a camera lucida mounted on a Leica MZ12.5 stereomicroscope, rendered on coquille board, scanned and finished in Adobe Illustrator (version CS3).

Expansion of the male pedipalp was accomplished by immersing it in a concentrated solution of $\mathrm{KOH}$, heating for 15 minutes beneath a desk lamp, and then transferring the pedipalp to tap water where expansion of the haematodochae occurred.

Scanning electron microscopy images were taken using a Leo 1450VP scanning electron microscope (SEM) at the California Academy of Sciences. Specimens were critical point dried, sputter coated with goldpalladium, and mounted on copper wire with generic white glue. A limited number of specimens were available for SEM analysis, and thus the description of features based on electron microscopy (e.g. spinneret spigot morphology) may understate variation.

For specimens examined, latitude-longitude coordinate pairs inferred from labels are given in square brackets; coordinates explicitly given on labels are not in square brackets. The distribution map was created with ArcView GIS software (version 9.2).

All anatomical images included in this publication have been deposited in Morphbank (http://www.morphbank.net). Specimen data have been exposed through the Global Biodiversity Information Facility (GBIF; http://data.gbif.org/welcome.htm). A KML (Keyhole Markup Language) file for viewing distribution records and online species pages interactively in Google Earth (http://earth.google.com/) is available as a supplementary file (http://www.mapress.com/zootaxa/2010/data/2534/Penestomidae.kml) All new nomenclatural acts have been registered with ZooBank (http://www.zoobank.org/). Web pages based on the content of this study have been created for the Encyclopedia of Life (http://www.eol.org/) using LifeDesks (http://www.lifedesks.org/). Where available, species descriptions and online pages include links to DNA sequence data posted on GenBank (http://www.ncbi.nlm.nih.gov/Entrez/). The taxonomic publication is available as an open access PDF (Arzberger et al. 2004; Eysenbach 2006; Lawrence 2001).

The following abbreviations are used throughout the text and figures:

Male pedipalp. C, conductor; E, embolus; K, keel on embolus; MA, median apophysis; RTA1, outer, bifid ramus of retrolateral tibial apophysis; RTA1(I), inner tip of outer ramus of retrolateral tibial apophysis; RTA1 $(\mathrm{O})$, outer tip of outer ramus of retrolateral tibial apophysis; RTA2, inner ramus of retrolateral tibial apophysis; R, ridge at base of RTA1; SU, suture; TG, tegulum.

Female genitalia. AL, anterior lobe; CD, copulatory duct; FD, fertilization duct; G, groove separating anterior from posterior lobes; MP, median projection of the AL; PA, posterolateral apophysis; PL, posterior lobe; S, spermatheca.

Spinnerets. AC, aciniform gland spigot; ALS, anterior lateral spinnerets; CR, cribellum; CY, cylindrical gland spigot; MAP, major ampullate gland spigot; mAP, minor ampullate gland spigot; MS, modified PLS spigot; n, nubbin; PI, piriform gland spigot; PLS, posterior lateral spinnerets; PMS, posterior median spinnerets; $t$, tartipore.

Specimens examined for this study are deposited at the following institutions: AMG, Albany Museum (Grahamstown); AMNH, American Museum of Natural History (New York); CAS, California Academy of Sciences (San Francisco); MHNG, Musée d'Histoire Naturelle (Genève); MNHN, Muséum National d'Histoire Naturelle (Paris); NCA, National Collection of Arachnida (Pretoria); SAM, Iziko South African Museum (Cape Town). 


\section{Short essay on cybertaxonomy}

In taxonomy today, we are witnessing a clash of cultures. The dominant view is influenced by the world of traditional publishing. According to this view, information should be published only once, and the concept of copyright helps to enforce this (Agosti \& Egloff 2009). The alternative view is perhaps best expressed in the world of computer science. Here, a guiding principal is that a piece of code should be written once, reused, shared, and even modified by others; so, write once, use many times. We assert that the latter model is more appropriate to taxonomy. Key elements of this work were disseminated through multiple venues, both print and electronic media, increasing the visibility, accessibility, and utility of our work.

Penev et al. (2009) proposed a model for publishing data elements online to enhance taxonomic works. Contributions to taxonomy are generally composed of only a few data classes. These include nomenclature, descriptions, images, specimen data, and increasingly molecular sequence data. There are now online resources that can aggregate and serve each of these data classes. In this work, we have adopted elements of the Penev model to make a network of data elements online, but without support from the publisher.

Within only the past few years, advances in technology and infrastructure have finally given us the tools to realize the full potential of taxonomy: an integrated consortium of resources for organizing, interconnecting, and recombining fundamental information about the world's biodiversity for multiple user groups (e.g. see Arzberger et al. 2004; Costello 2009; Godfray et al. 2007; Scoble et al. 2007; Wheeler 2008). We could see a steady stream of specimen data linked to peer reviewed taxonomic publications becoming available online. In electronic form, specimen data from multiple sources could be recombined and analyzed by anyone online, including ecologists, conservation organizations, and land use planners. A mature Encyclopedia of Life would empower the public to develop their personal bioliteracy (Gewin 2002; Wilson 2003). By serving the information we have traditionally produced in more diverse and flexible forms, taxonomists will demonstrate renewed value and relevance to multiple groups of information consumers. The decline in taxonomic expertise is well documented (House of Lords 2008; Lee 2000). Cybertaxonomy gives us an opportunity to reverse this trend by demonstrating the power and utility of the data our community produces. All this without fundamentally changing what we do, only what we do with it.

\section{Systematics}

\section{Family Penestomidae Simon, 1903}

Penestominae Simon, 1903: 979. Type genus Penestomus Simon, 1902. Lehtinen, 1967: 385-390; Dippenaar-Schoeman, 1989: 131.

Penestomidae. Miller et al., 2010: 801.

Affinities. Removal of the Penestominae from the Eresidae was justified by analysis of molecular sequence data (Miller et al. 2010). These data consistently indicated that penestomines are close to the Zodariidae, and that this relationship has significantly better support than one constrained to include a monophyletic Eresidae including Penestominae (Shimodaira \& Hasegawa 1999). One line of morphological evidence that could support a close relationship between zodariids and penestomids has to do with the arrangement of spigots on the anterior lateral spinnerets. Typically, the major ampullate gland spigots (MAP) are placed on the margin of the spinning field (e.g. see Griswold et al. 2005, fig. 49B) but in both zodariids (Miller et al. 2010, fig. 2E) and penestomids (Fig. 6B) the MAP are placed in the center of the field of piriform gland spigots (PI).

The Zodariidae are diagnosed by several characters not found in Penestominae (i.e. absence of serrula, lateral implantation of tarsal claw teeth, long anterior lateral spinnerets; see Jocqué 1991). Inclusion of Penestominae within the entirely ecribellate Zodariidae would radically change and complicate the diagnosis of this expanded family concept. For these reasons, Miller et al. (2010) promoted Penestominae to family rank. 
Penestomus Simon, 1902: 241. Type species by monotypy Penestomus planus Simon, 1902. Simon, 1903: 980; Lehtinen, 1967: 257, 385-390; Dippenaar-Schoeman, 1989: 131.

Wajane Lehtinen, 1967: 275. Type species by monotypy Wajane armata Lehtinen, 1967. Dippenaar-Schoeman, 1989: 133. New synonymy.

Justification of synonymy. Wajane was described by Lehtinen (1967) based on a single male specimen. At the time, Penestomus was known only from females. The chief diagnostic character for distinguishing Penestomus from Wajane was the lack of a cribellum in the latter. However, male spiders almost never have a cribellum, even when conspecific females do, and Lehtinen himself speculated that Wajane females could have a functional cribellum (Lehtinen 1967: 387). Dippenaar-Schoeman (1989) described W. stilleri in the genus Wajane based on its reported lack of a cribellum but electron microscopy of W. stilleri non-type material clearly indicates that a functional cribellum is present (Fig. 8F). A total of three penestomid species are now known from males. While all differ in detail (especially of the pedipalp), there are no obvious characters that would suggest two distinct clades that could be circumscribed as Penestomus and Wajane. Wajane is thus hereby synonymised with Penestomus.

Diagnosis. Distinguished from other three-clawed, eight-eyed, cribellate entelegyne spiders except Eresidae by their subrectangular carapace (Fig. 1B) and clypeal hood (Fig. 1C); distinguished from Eresidae by the flat body (Fig. 1A), tapetum in the indirect eyes (Fig. 1D), RTA on the male pedipalpal tibia and by the position of the posterior lateral eyes, which are several eye diameters behind the posterior median eyes in Eresidae but are less than three eye diameters behind the posterior median eyes in Penestomidae (Fig. 1C). Distinguished from the ecribellate Zodariidae by the presence of a cribellum (Fig. 5A) and calamistrum (Fig. 4C), a serrula on the endites (Fig. 2A), a clypeal hood (Fig. 1C), and by the absence of tarsal trichobothria.

Description. Flat spiders (Fig. 1A). Total length 3-6. Carapace subrectangular with shallow ovoid fovea. Eight eyes in two rows, posterior eye row slightly recurved, more widely spaced than anteriors (Fig. 1C). Tapetum present in indirect eyes (ALE, PLE, PME), at least that of PME appears to be canoe-shaped (Fig. 1D). Carapace, legs, and abdomen usually with two setal morphologies, one black and filiform, the other white and plumose (Figs 1B, E). Sternum ovoid, longer than wide, not fused to labium (Fig. 1F). Endites parallel, with serrula. Anterior surface of labrum with bifid lingual process (Fig. 2B). Chelicerae with boss (Fig. 2C). Promargin of fang furrow armed with four-six teeth increasing in size from base of fang to the penultimate tooth; proximal tooth small. Retromargin of fang furrow armed with two-three teeth (Fig. 2D; contra Dippenaar-Schoeman 1989; Lehtinen 1967). Respiratory system with pair of book lungs anteriorly; posterior tracheal system (examined in a penultimate juvenile of $P$. egazini sp. nov.) quadritracheate, with four simple, subequal tubes restricted to abdomen. Female pedipalp with dentate claw; tarsus with pro-ventral cluster of macrosetae. Leg tarsi each with multidentate paired claws and untoothed median claw (Fig. 2E); scopula absent. Tarsal organ capsulate, on slightly raised base; opening circular (Fig. 2F). Tibiae each with two dorsal rows of trichobothria; metatarsi each with one dorsal trichobothrium distally; bothria hooded (Fig. 4A); tarsi without trichobothria. Male tibiae and metatarsi I with clusters of retrolateral macrosetae (Figs 3BD); tibiae II-IV with visible transverse suture near base (Fig. 3A; see also Griswold 1993, 1994; Griswold et al. 2005). Female with calamistrum, a single row of setae occupying distal two thirds of metatarsus IV (Fig. 4C). Female cribellum divided with two fields of strobilate spigots (Figs 5E, F). Female anterior lateral spinnerets (ALS) with two major ampullate gland spigots (MAP) on squat bases, these invaginated into piriform (PI) field, four PI on tall tapered bases, plus approximately four tartipores (Fig. 5B). Female posterior median spinnerets (PMS) with two minor ampullate gland spigots (mAP), one aciniform gland spigot (AC), one tartipore, and two cylindrical gland spigots (CY; Fig. 5C). Female PLS with one modified spigot (MS) flanked by two nubbins, four aciniform gland spigots (AC), one tartipore, and one CY (Fig. 5D). Paracribellar spigots absent from both the PLS and PMS. Male cribellum vestigial, lacking spigots (Fig. 6A). Male ALS with one MAP on a squat base plus one nubbin, these within the PI field, four PI on tall tapered bases, and approximately three tartipores. Male PMS with one mAP, one nubbin (representing a mAP), one anterior AC, and one tartipore (Fig. 6C). Male PLS with one nubbin (representing the MS), seven AC, and three tartipores (Fig. 6D). Epiandrum with two clusters of about 5-10 spigots (Fig. 4B). 

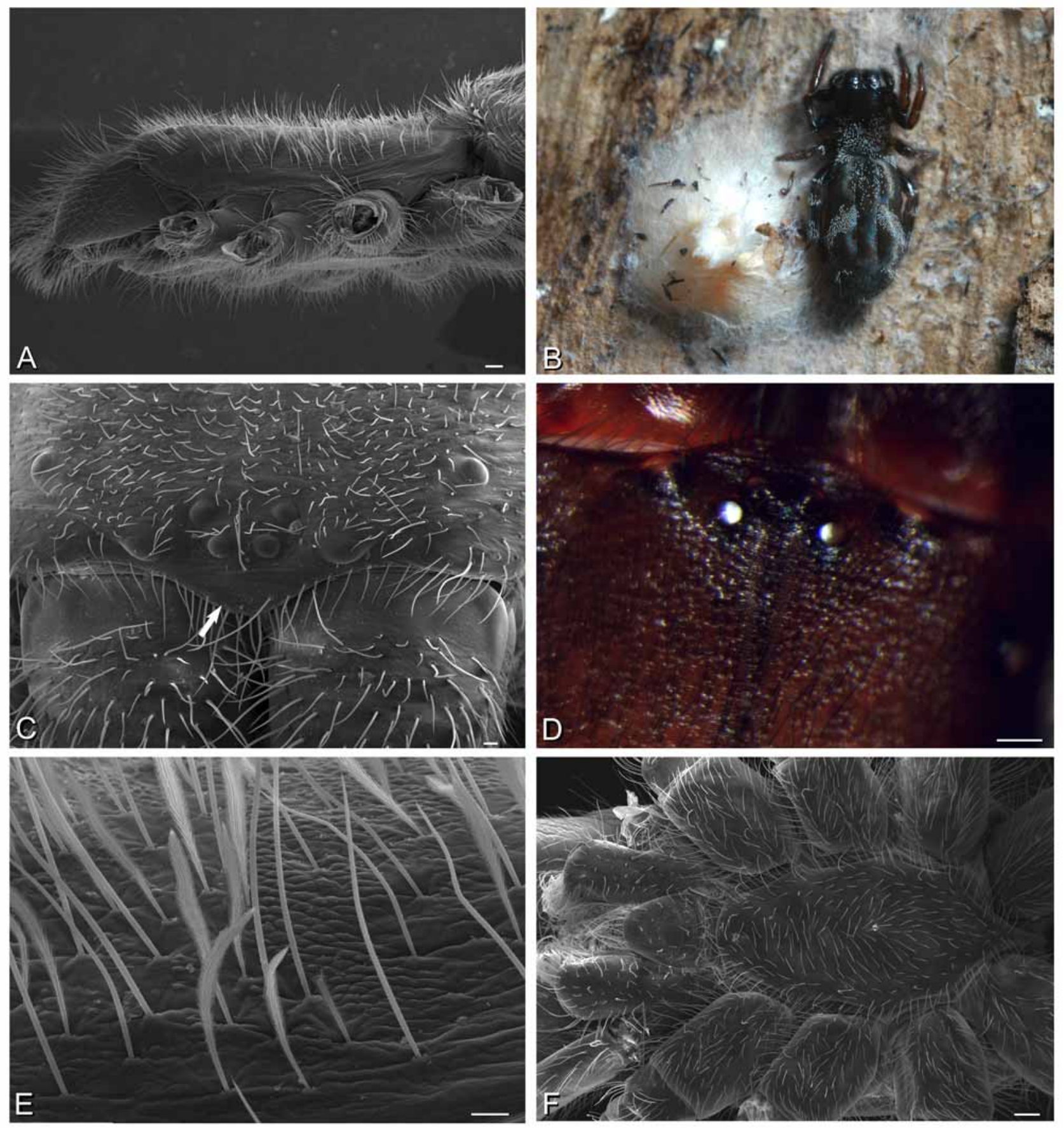

FIGURE 1. Penestomus egazini sp. nov. females from Grahamstown, South Africa (A, C, E, F, CASENT 9024961; B, CASENT 9023774; D, CASENT 9024964). A, prosoma, lateral view; B, live female with egg case under Eucalyptus bark; C, prosoma, anterior view, arrow indicates clypeal hood; $\mathrm{D}$, light micrograph showing tapetum in posterior median eyes; E, detail of carapace, lateral view, showing plumose and filiform types of setae; F, prosoma, ventral view. A, C, EF, scanning electron micrographs; B, field photograph; D, light micrograph of specimen under stereomicroscope. Scale bars $A, F=100 \mu \mathrm{m} ; C, E=30 \mu \mathrm{m} ; \mathrm{D}=0.1 \mathrm{~mm}$.

Male pedipalpal tibia with apophyses arising from the retrolateral part of tibia (the retrolateral tibial apophysis or RTA), which comprise an inner ramus of the RTA (RTA2) that arises apically near the base of the cymbium (Fig. 7B) and an outer, bifid ramus of the RTA (RTA1) that arises basally on the tibia and that is divided apically into inner RTA1(I) and outer RTA1(O) tips (Fig. 7F). Base of RTA1 with ridge (R). Median apophysis (MA) anchored to retrolateral side of tegulum by membranous tissue, with notched plate on 
retrolateral side and long tailpiece extending transversely across the proximal tegulum to prolateral side of bulb (Fig. 7C). Conductor (C) retroapical, fleshy, translucent (Figs 7D, 10A). Embolus makes a half turn, tip expanded and complex, rests against conductor in unexpanded conformation (Figs 7C, 10A). Expansion of the bulb reveals a long, narrow, heavily sclerotized petiole that extends two-thirds the retrolateral height of the alveolus, the prodorsal surface of the tegulum with a conical projection that fits into a corresponding depression on the subtegulum (Fig. 11B), and a reservoir that makes a simple loop around the margin of the tegulum and subtegulum, without switchbacks.
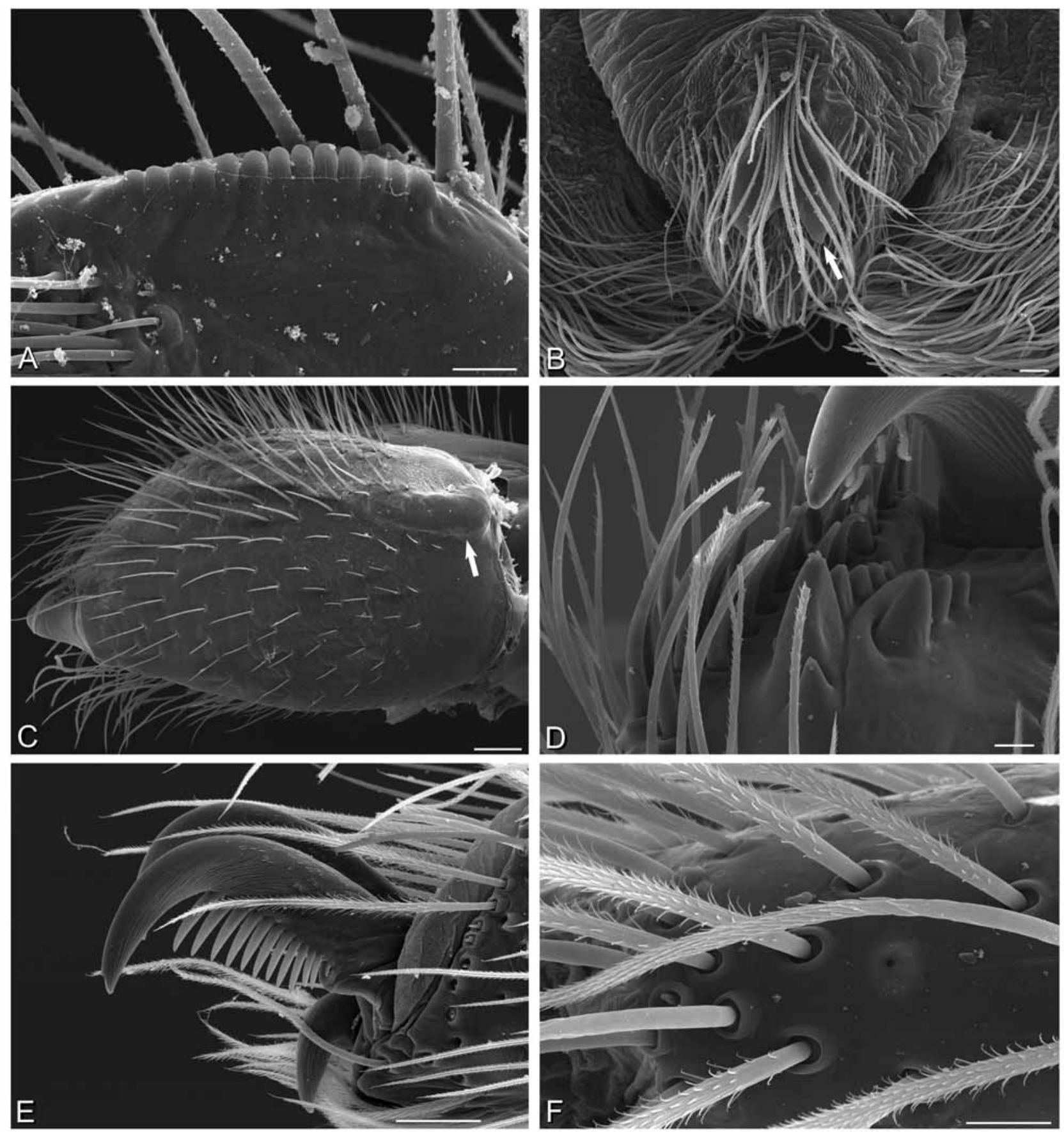

FIGURE 2. Penestomus egazini sp. nov. from Grahamstown, South Africa (A, B, E, F, female, CASENT 9024964; C, D, male, CASENT 9024985), scanning electron micrographs. A, detail of endite showing serrula, anterior view; B, labrum, anterior view, chelicerae removed, arrow indicated bifid lingual process; C, chelicera, lateral view, arrow indicates boss; D, chelicera showing fang and teeth; E, claws, left tarsus IV; F, tarsal organ, tarsus I. A, B taken from specimen with chelicerae removed; $\mathrm{C}$ shows chelicera removed from prosoma and mounted separately. Scale bars A, E, $\mathrm{F}=20 \mu \mathrm{m} ; \mathrm{B}=30 \mu \mathrm{m} ; \mathrm{C}, \mathrm{D}=100 \mu \mathrm{m}$. 

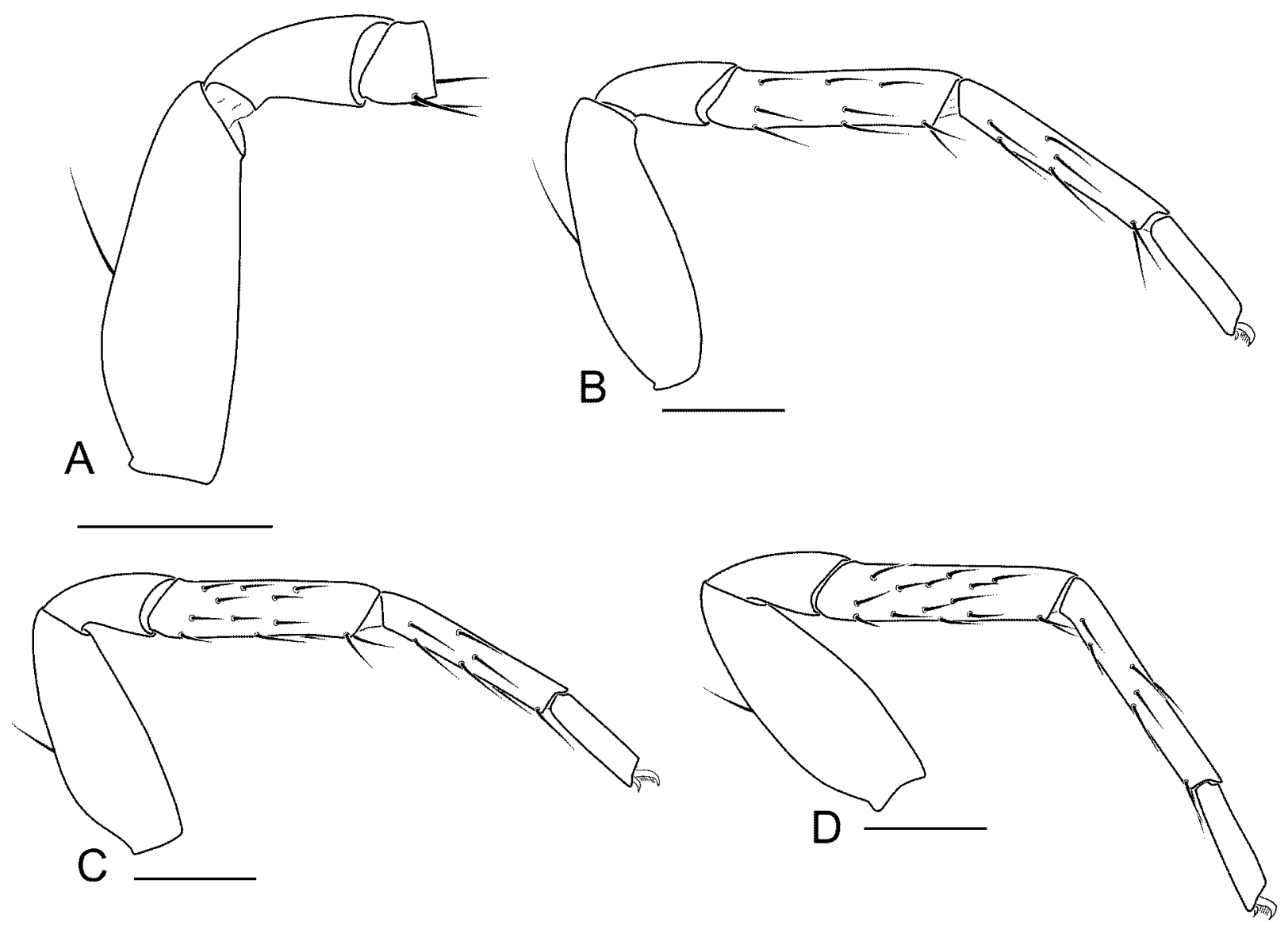

FIGURE 3. Male legs of Penestomus species, retrolateral view. A, C, P. montanus sp. nov. from Qacha's Nek, Lesotho (AcAT 2006/1535); B, P. egazini sp. nov. from Grahamstown, South Africa (CASENT 9024985); D, P. armatus (Lehtinen, 1967) from Alicedale, South Africa (holotype of Wajane armata). A, leg II showing tibia broken at suture; BD, leg I. Scale bars $=0.5 \mathrm{~mm}$.

Female genitalia entelegyne, epigynum divided into anterior lobe (AL) and posterior lobe (PL; Fig. 12A). Epigynum usually mushroom-shaped (a subtriangular anterior lobe with a long, narrow posterior lobe), occasionally subpentagonal (Fig. 16E). Median projection of AL runs posteriorly into PL, divided from PL by a groove laterally and posteriorly (Fig. 8A). Pair of (usually membranous) posterolateral apophyses (PA) arise from AL on either side of the median projection (MP)/PL complex (Figs 8A, E). AL usually with pair of unsclerotized anterolateral patches (Fig. 12A). Spermathecae (S) usually subspherical, occasionally ovoid (Figs 8B, 16H); fertilization ducts (FD) and copulatory ducts (CD) originate from posteromesal region of spermathecae (Fig. 12D). CD path direct, gently curved or sinuous, running posteriorly from spermathecae (Fig. 8B). FD relatively robust, gently curved, running posteriorly from spermathecae (Fig. 8B).

Previous authors have erroneously suggested that penestomids lack teeth on the posterior margin of the fang furrow (Dippenaar-Schoeman 1989; Lehtinen 1967). The lack of posterior margin teeth has also been claimed in eresines, although in fact the teeth are merely small (Griswold et al. 2005: fig. 131D). Lehtinen (1967: 388) asserted that there were instead two rows of teeth along the anterior margin. In fact, penestomids have fpur to six teeth on the promargin and two to three teeth on the retromargin of the fang furrow (Fig. 2D).

Species groups. Based on morphology of female genitalia, most penestomid species resemble the type species $P$. planus in possessing a mushroom-shaped epigynum (a subtriangular anterior lobe with a long, narrow posterior lobe; Fig. 16A). Penestomus croeseri and P. stilleri are both quite distinct from the P. planus configuration and from each other. All remaining species (P. planus, $P$. egazini sp. nov., $P$. kruger sp. nov., $P$. montanus sp. nov., P. prendinii sp. nov., $P$. zulu sp. nov.) are placed in the planus group. Females of planus group species are distinguished from $P$. stilleri by the subspherical spermathecae (Figs 8B, 12B, D, F, 16D; 
ovoid in P. stilleri, Fig. 16H); from P. croeseri by the connection between the AL and its MP (as wide as the MP in planus group species, Figs 12A, C, E, 16A, B, C; distinctly narrower in P. croeseri, Fig. 16E). Since the female of $P$. armatus is unknown, it is not possible to infer its affinities at this time. But if the female is discovered and it resembles $P$. croeseri, $P$. stilleri, or has a unique configuration, this could justify the resurrection of Wajane.
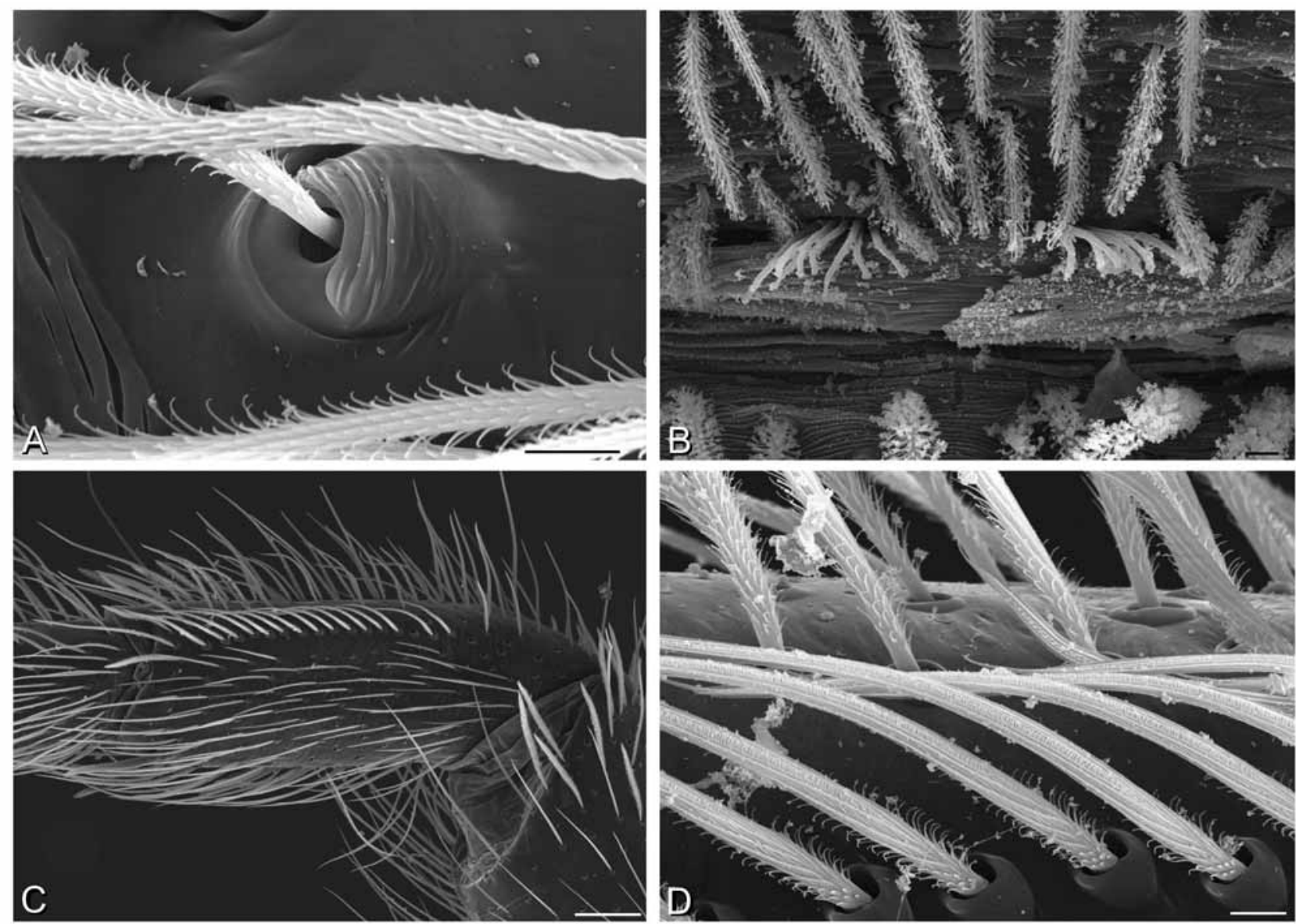

FIGURE 4. Penestomus egazini sp. nov. from Grahamstown, South Africa (A, C, D, female, CASENT 9024964; B, male, CASENT 9024985), scanning electron micrographs. A, trichobothrium, metatarsus I; B, epiandrous gland spigots; C, left metatarsus IV showing calamistrum; D, calamistrum setae detail. Scale bars $\mathrm{A}, \mathrm{B}, \mathrm{D}=10 \mu \mathrm{m} ; \mathrm{C}=100 \mu \mathrm{m}$.

\section{Key to the species of Penestomus}

Males of $P$. prendinii sp. nov., P. planus Simon, 1902, P. kruger sp. nov., $P$. zulu sp. nov., $P$. croeseri Dippenaar-Schoeman, 1989 and $P$. stilleri (Dippenaar-Schoeman, 1989) are unknown. Females of $P$. armatus are unknown.

1. Males 2

Females

2(1) Transverse tailpiece of MA without lobe on anterior margin; embolus tip bifid; bifurcate tips of RTA1 long (Fig. 10A); apex of RTA2 curved dorsally (Fig. 10C).

Transverse tailpiece of MA with lobe on anterior margin; embolus tip subrectangular and entire; bifurcate tips of RTA1 short (Fig. 14A); apex of RTA2 projecting distally (Fig. 14C)

P. montanus sp. nov.

3(2) Embolus with a short dorsal keel (Fig. 10A); apex of RTA2 long (Fig. 10C) Embolus lacking keel; apex of RTA2 short (Fig. 20C).

4(1) Spermathecae subspherical, longest axis less than 1.5 times the narrowest, not diverging posteriorly (Fig. 12B); epigynum subpentagonal (Fig. 16E) or mushroom-shaped (Fig. 12A). 
Spermathecae longitudinally ovoid (Fig. 16H), longest axis about twice the narrowest, diverging posteriorly; epigynum subpentagonal (Fig. 16G)......

5(4) Epigynum with MP longer than wide, broadly connected to AL, MP without convex lateral margins (Figs 8A, 12A); subpentagonal or mushroom-shaped

Epigynum with MP wider than long with a narrow waist anteriorly and convex lateral margins; subpentagonal (Fig. 16E) P. croeseri Dippenaar-Schoeman, 1989

6(5) Epigynum PL without invagination on posterior margin (Fig. 12B).... 7 Epigynum PL with invagination at center of posterior margin (Fig. 16D) P. zulu sp. nov.

7(6) Carapace in dorsal view with sides parallel (Fig. 9A); epigynum with AL posterior margin straight or evenly con-

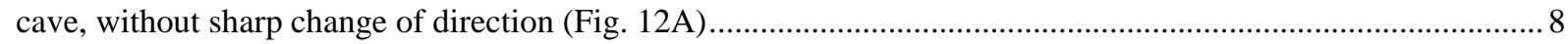
Carapace in dorsal view with sides rounded (Fig. 15A); epigynum with AL posterior margin straight medially, turns sharply to form lateral corners that project somewhat more posteriorly (Fig. 12E) ........... prendinii sp. nov.

8(7) Grooves on PL nearly parallel; AL clearly demarcated posteriorly (Fig. 12A)..... 9 Grooves on PL diverging posteriorly; AL posterior margin indistinct (Fig. 12C) P. montanus sp. nov.

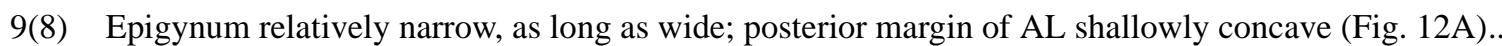
10 Epigynum relatively broad, wider than long; posterior margin of AL deeply concave (Fig. 16A)

P. planus Simon, 1902

10(9) Epigynum PL long, nearly one half total epigynal length (Fig. 12A); metatarsus I with 2 pairs of ventral macrosetae..... P. egazini sp. nov. Epigynum PL short, less than one third total epigynal length (Fig. 16B); metatarsus I with 3 pairs of ventral macrosetae P. kruger sp. nov.

\section{Penestomus egazini sp. nov.}

http://zoobank.org/urn:lsid:zoobank.org:act:0A23DECF-8B4F-408E-B0C5-F990298631E8 Figs 1, 2, 3B, 4-7, 8A-D, 9-11, 12A, B, 21

Penestomus sp. nov. 1: Miller et al., 2010, figs 1A, 1C, 2A, 2C, 2F. GenBank accession numbers FJ948973 (28S rDNA),

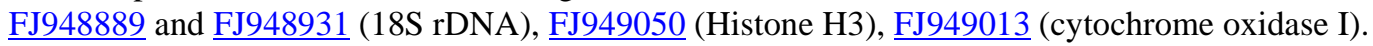

Type material. Holotype: $q$, Grahamstown Municipal Caravan Park, Eastern Cape, South Africa, 33⒚166'S, 26³1.426'E, 580 m, 10-19 February 2006, under Eucalyptus bark, J. Miller, H. Wood, L. Lotz (CASENT 9024958, deposited in NCA). Paratypes: 1 ô, same data as holotype (CASENT 9024985, CAS; reared to adulthood in the laboratory over a period of approximately nine months from collection); 2 , 1 juvenile, same data as holotype (CASENT 9024962, CAS); 2 q, 1 juvenile, same data as holotype (CASENT 9024964, CAS); 4 \% , 5 juveniles, same data as holotype (CASENT 9024957, CAS); 3 o, 15 juveniles, same data as holotype (CASENT 9024965, CAS); 3 q, 1 juvenile, same data as holotype (CASENT 9024961, CAS); 1 q, same data as holotype (CASENT 9023774, CAS, DNA voucher JM8-15); 1 q, same data as holotype (CASENT 9023775, CAS); 1 o, 1 juvenile, same data as holotype (CASENT 9024960, CAS), with

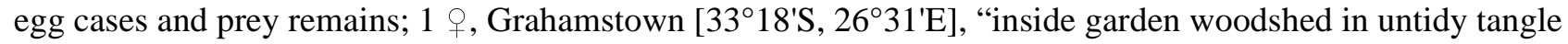
of web next to glass pane, web like eresid but spider belongs to another group, egg sac enclosed" (AcAT 2007/1541, NCA).

Additional material examined. SOUTH AFRICA: Eastern Cape: 6 ㅇ, 2 juveniles, Alicedale $\left[31.467^{\circ} \mathrm{S}\right.$, $\left.25.850^{\circ} \mathrm{E}\right]$, December 1914, F. Cruden (AMG).

Etymology. The specific epithet is a noun in apposition, named after the site of a pivotal 1819 battle in which the Xhosa, led by Maqana Nxele, attacked the British garrison in Grahamstown. 

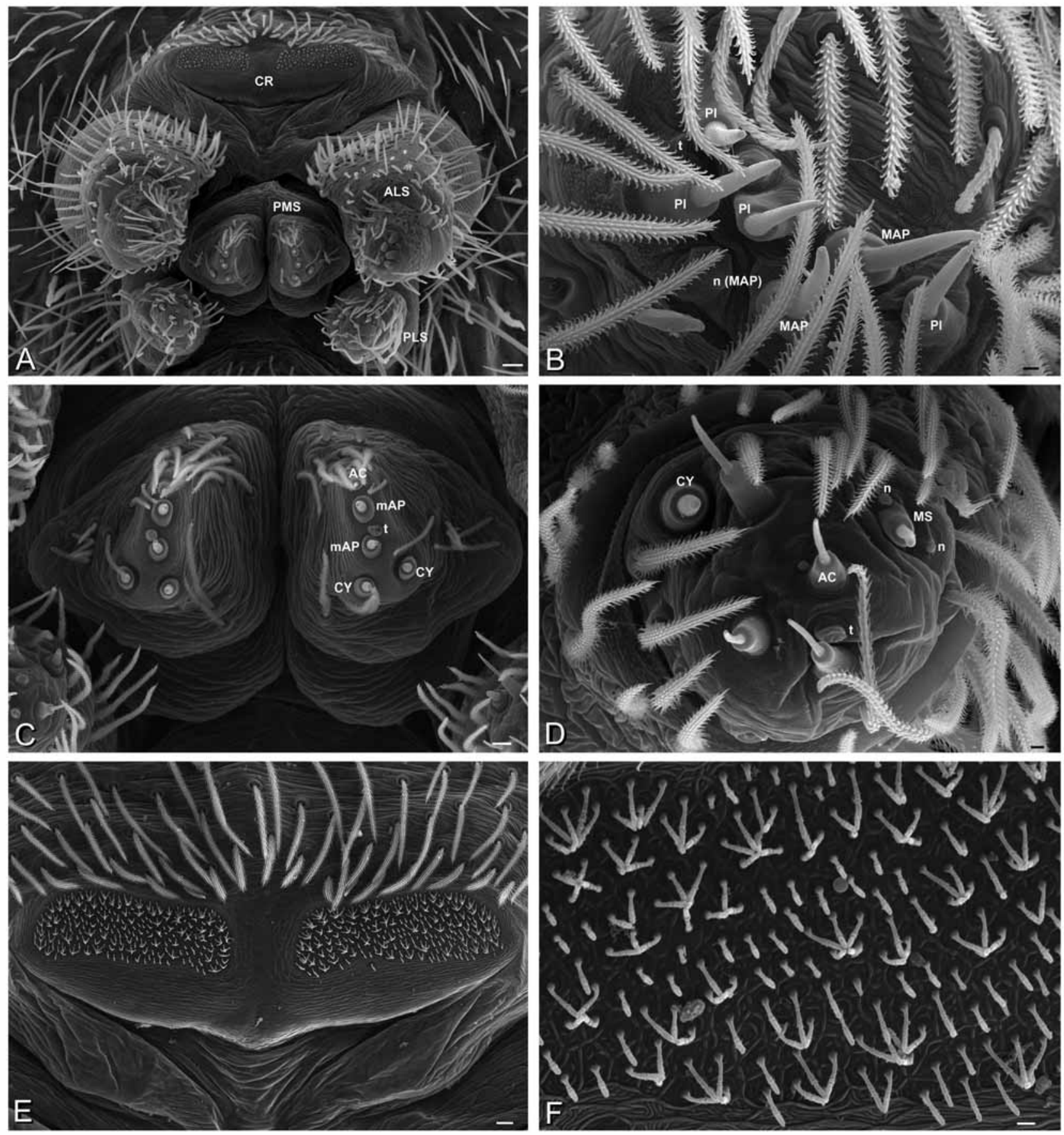

FIGURE 5. Penestomus egazini sp. nov. from Grahamstown, South Africa (A, C-F, CASENT 9024961; B, CASENT 9024964), scanning electron micrographs of female spinnerets. A, spinnerets; B, anterior lateral spinneret, right side; C, posterior median spinnerets; D, posterior lateral spinneret, left side; E, cribellum; F, detail, cribellar spigots. Scale bars A $=30 \mu \mathrm{m} ; \mathrm{B}, \mathrm{D}=3 \mu \mathrm{m} ; \mathrm{C}, \mathrm{E}=10 \mu \mathrm{m} ; \mathrm{F}=2 \mu \mathrm{m}$. AC, aciniform gland spigot; ALS, anterior lateral spinnerets; CR, cribellum; CY, cylindrical gland spigot; MAP, major ampullate gland spigot; mAP, minor ampullate gland spigot; MS, PLS modified spigot; n, nubbin; PI, piriform gland spigot; PLS, posterior lateral spinnerets; PMS, posterior median spinnerets; t, tartipore.

Diagnosis. Male distinguished by the presence of a keel on the outer margin of the embolus near the distal maximum of the embolic arc (Figs 7C, 10A), absent from other species (Fig. 14A). 
Female distinguished from other planus group species as follows: from $P$. zulu sp. nov. by the lack of an invagination on the posterior margin of the PL (Fig. 16D); from the remaining planus group species by the posterior margin of the AL, which is only slightly recurved and farther from the epigastric furrow than in other species (Fig. 12A). Further distinguished by the presence of only two rows of ventral macrosetae on the first tibiae and metatarsi, with three rows in other species.

Description. Carapace brown, rugose, covered by fine black setae, with broad white setae concentrated in thoracic region (Fig. 9A). Sternum dusky pale yellow (Fig. 9B). Chelicerae brown, with six promarginal teeth, three retromarginal teeth (Fig. 2D); with fine black setae only. Legs brown basally, pale yellow distally. Abdomen dark gray dorsally with pair of narrow light dorsolateral patches, covered with mixture of fine black and broad white setae (Fig. 9A).

Male pedipalp: Outer retrolateral tibial apophysis (RTA1) with tips long, diverging, inside tip curved ventrally (Figs 7F, 10A). Dorsal ridge long, extending from base of RTA1 nearly to bifid part (Fig. 7F). RTA2 with apex long, slender, curved dorsally (Figs 7B, 10C). MA without anterior lobe arising from tail. Embolus with keel along outer margin terminating near distal maximum of embolic arc forming notch; bifid distal region formed from transparent dorsal process and pointed distal tip (Figs 7F, 10A).

Epigynum: AL subtriangular, clearly differentiated from surrounding cuticle, posterior margin concave; PL nearly half length of epigynum, with parallel grooves (Fig. 12A).
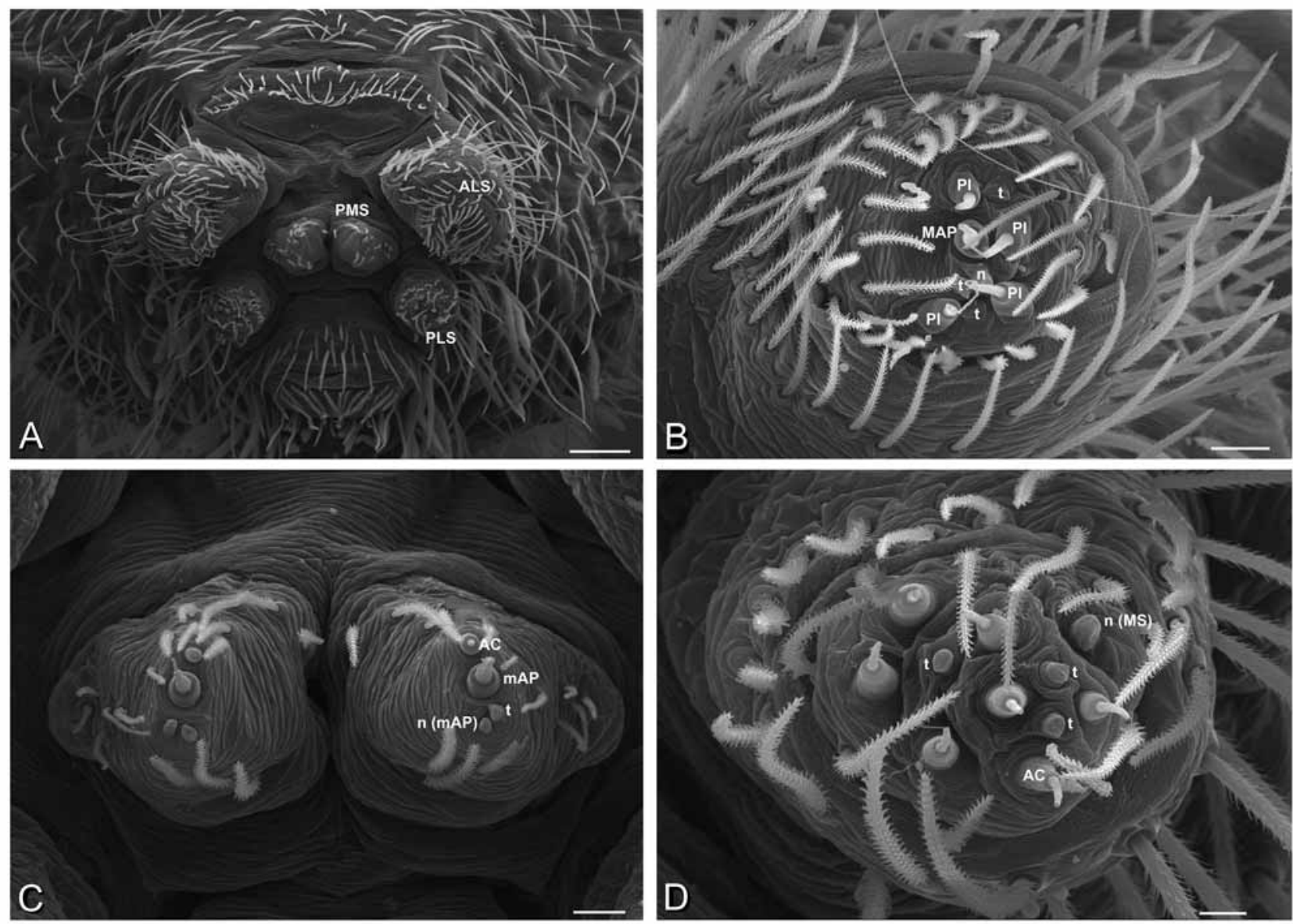

FIGURE 6. Penestomus egazini sp. nov. from Grahamstown, South Africa (CASENT 9024985), scanning electron micrographs of male spinnerets. A, spinnerets; B, anterior lateral spinneret, left side; C, posterior median spinnerets; D, posterior lateral spinneret, left side. Scale bars $A=100 \mu \mathrm{m} ; \mathrm{B}, \mathrm{C}=20 \mu \mathrm{m} ; \mathrm{D}=10 \mu \mathrm{m}$. AC, aciniform gland spigot; ALS, anterior lateral spinnerets; MAP, major ampullate gland spigot; mAP, minor ampullate gland spigot; MS, PLS modified spigot; n, nubbin; PI, piriform gland spigot; PLS, posterior lateral spinnerets; PMS, posterior median spinnerets; $\mathrm{t}$, tartipore. 
Male macrosetae: Leg I: femur d1, tibia r2-1-2, v1-2-2, metatarsus r1-1, v2-2-2; leg II: femur d1, tibia r22, v2-2-2, metatarsus r1-1, v2-2; leg III: femur d1, tibia p1-1, r1, v2-2-2, metatarsus p1, r1-2, v1-2; leg IV: femur d1, tibia p1-1-1-1-2-1, v2-2-2-2, metatarsus p1-1, r1, v1-2, tarsus r1.

Female macrosetae: Leg I: tibia v1-2, metatarsus v2-2; leg II: metatarsus v2-2; leg III: metatarsus v2; leg IV: metatarsus v1-1-2, tarsus $r 1$. All femora with one dorsal seta slightly thicker and longer than the others.
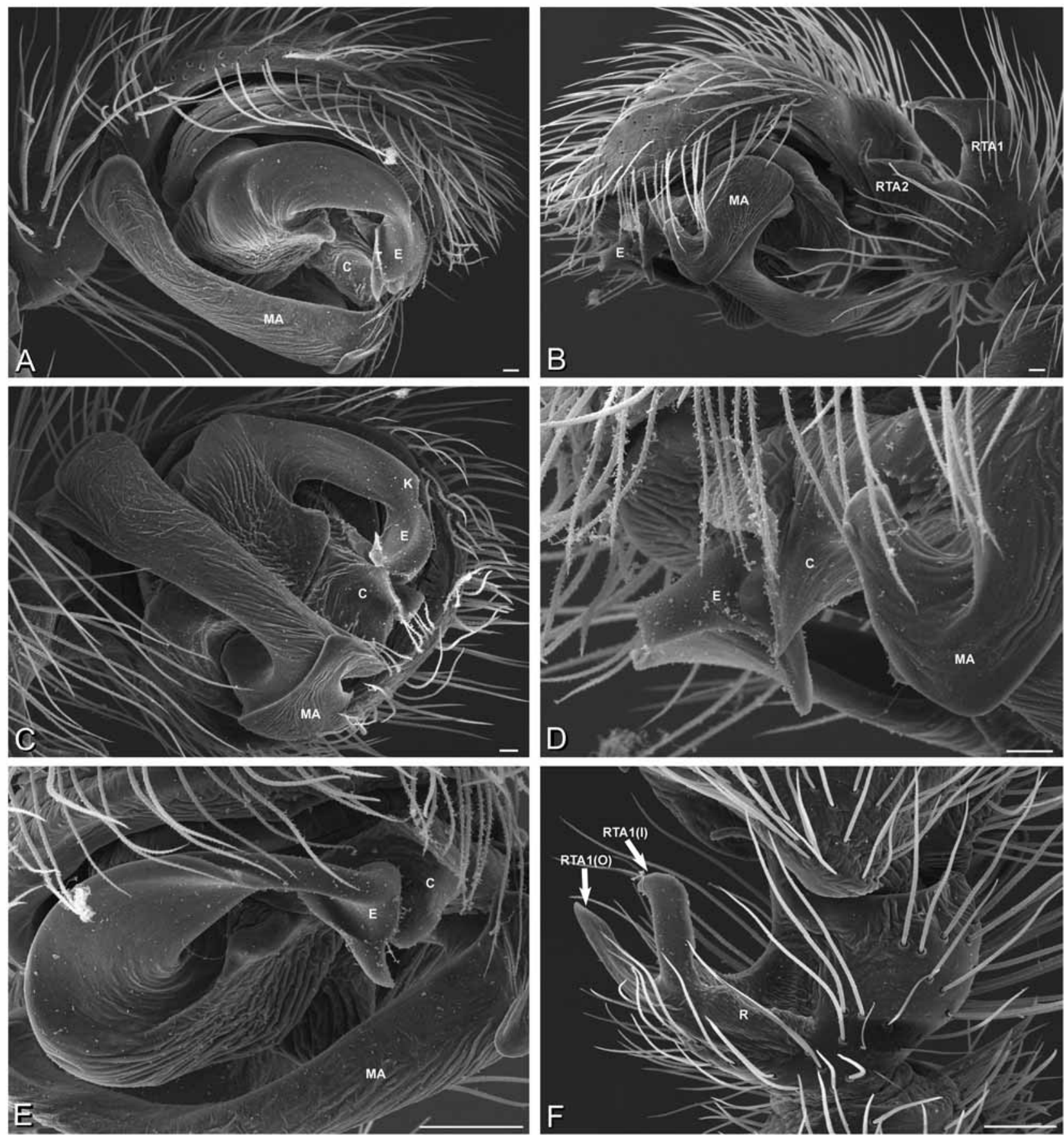

FIGURE 7. Penestomus egazini sp. nov. from Grahamstown, South Africa (CASENT 9024985), scanning electron micrographs of left male pedipalp. A, prolateral view; B, retrolateral view; C, ventral view; D, detail of embolus tip, retrolateral view; E, detail of embolus tip, prolateral view; F, tibia, dorsal view. Scale bars $A-D=30 \mu \mathrm{m} ; \mathrm{E}, \mathrm{F}=100 \mu \mathrm{m}$. C, conductor; E, embolus; K, keel on embolus; MA, median apophysis; RTA1, outer, bifid ramus of retrolateral tibial apophysis; RTA1(I), inner tip of outer ramus of retrolateral tibial apophysis; RTA1(O), outer tip of outer ramus of retrolateral tibial apophysis; RTA2, inner ramus of retrolateral tibial apophysis; R, ridge at base of RTA1. 

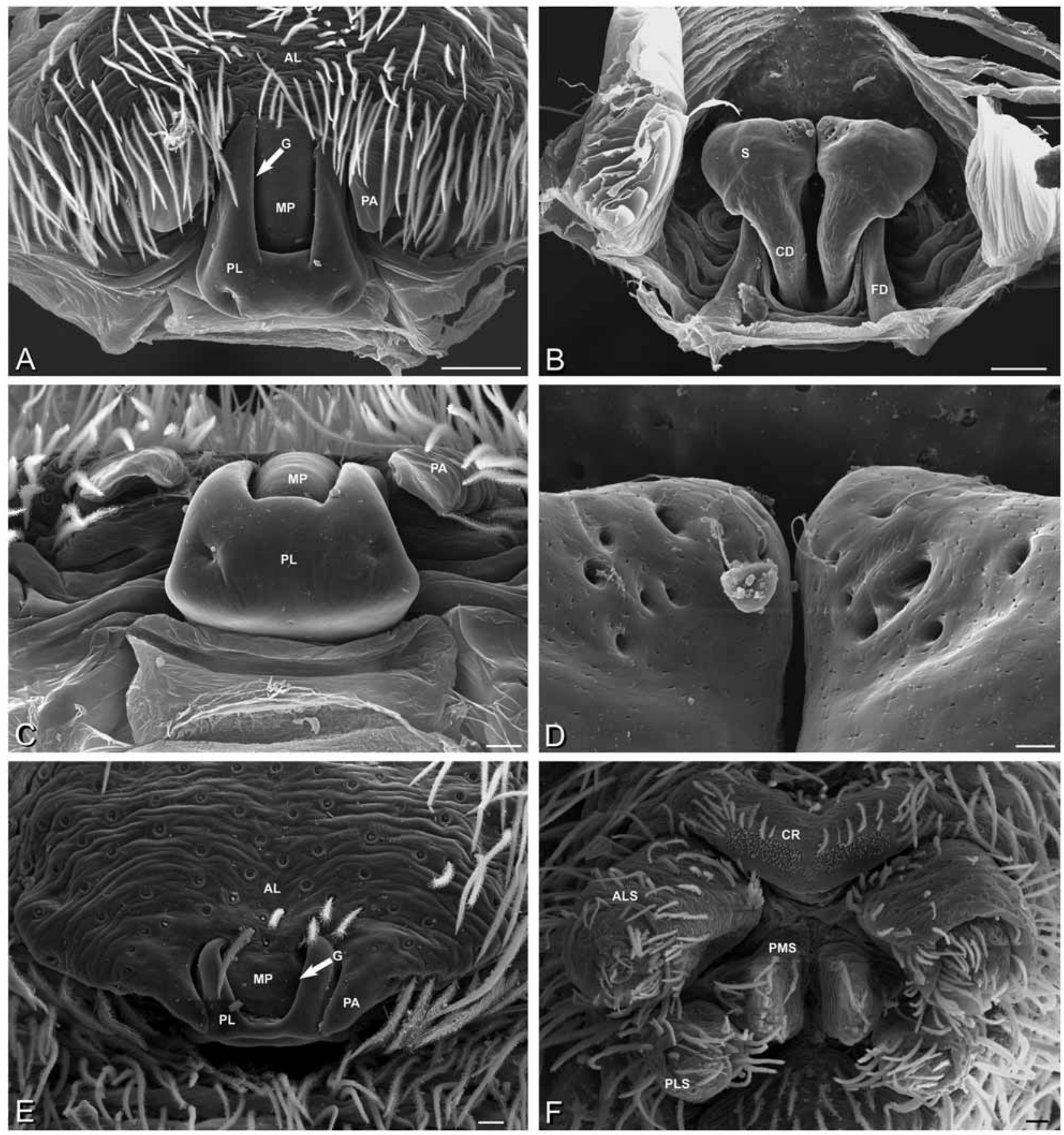

FIGURE 8. A-D, Penestomus egazini sp. nov. from Grahamstown, South Africa (A, female, CASENT 9024961; B-D, female, CASENT 9024964); E, F, P. stilleri (Dippenaar-Schoeman, 1989) from Winterhoek, South Africa (B2853, SAMENW-B002853). A-E, epigynum; F, spinnerets. A, E, ventral view; B, D, dorsal view; C, posterior view; F, spinnerets including functional cribellum. Scale bars $A, B=100 \mu \mathrm{m} ; C=30 \mu \mathrm{m} ; \mathrm{D}=10 \mu \mathrm{m} ; \mathrm{E}, \mathrm{F}=20 \mu \mathrm{m}$. AL, anterior lobe; CD, copulatory duct; $\mathrm{CR}$, cribellum; FD, fertilization duct; G, groove; MP, median projection of the AL; PA, posterolateral apophysis; PL, posterior lobe; S, spermatheca; ALS, anterior lateral spinnerets; PLS, posterior lateral spinnerets; PMS, posterior median spinnerets. 
Paratype male (CASENT 9024962): Total length 5.3, carapace 2.22 long, 1.61 wide, 0.45 high, sternum 1.23 long, 0.75 wide. Leg measurements:

$\begin{array}{lcccc} & \text { I } & \text { II } & \text { III } & \text { IV } \\ \text { Femur } & 1.13 & 1.08 & 0.87 & 1.27 \\ \text { Patella } & 0.60 & 0.57 & 0.46 & 0.63 \\ \text { Tibia } & 0.87 & 0.71 & 0.56 & 1.04 \\ \text { Metatarsus } & 0.99 & 0.87 & 0.67 & 0.83 \\ \text { Tarsus } & \underline{0.53} & \underline{0.40} & \underline{0.33} & \underline{\mathbf{4 . 6 3}} \\ \text { Total } & \mathbf{4 . 1 3} & \mathbf{3 . 6 3} & \mathbf{4 . 8 9}\end{array}$

Holotype female (CASENT 9024985): Total length 4.6, carapace 1.75 long, 1.30 wide, 0.38 high, sternum 1.06 long, 0.59 wide. Leg measurements:

$\begin{array}{lccccc} & \text { I } & \text { II } & \text { III } & \text { IV } & \text { Pedipalp } \\ \text { Femur } & 0.80 & 0.76 & 0.63 & 0.99 & 0.45 \\ \text { Patella } & 0.46 & 0.43 & 0.37 & 0.54 & 0.21 \\ \text { Tibia } & 0.51 & 0.46 & 0.38 & 0.81 & 0.19 \\ \text { Metatarsus } & 0.54 & 0.49 & 0.36 & 0.56 & - \\ \text { Tarsus } & \underline{0.29} & \underline{0.29} & \underline{0.22} & \underline{0.25} & \underline{\mathbf{0 . 3 8}} \\ \text { Total } & \mathbf{2 . 6 0} & \mathbf{2 . 4 3} & \mathbf{1 . 9 7} & \mathbf{3 . 1 4} & \mathbf{1 . 2 3}\end{array}$

Natural history. Prey remains (CASENT 9024960) suggest a diet dominated by Formicidae (especially Camponotus and Lepisiota) with some Coleoptera and Hemiptera.

Distribution. Known from Eastern Cape Province, South Africa (Fig. 21).
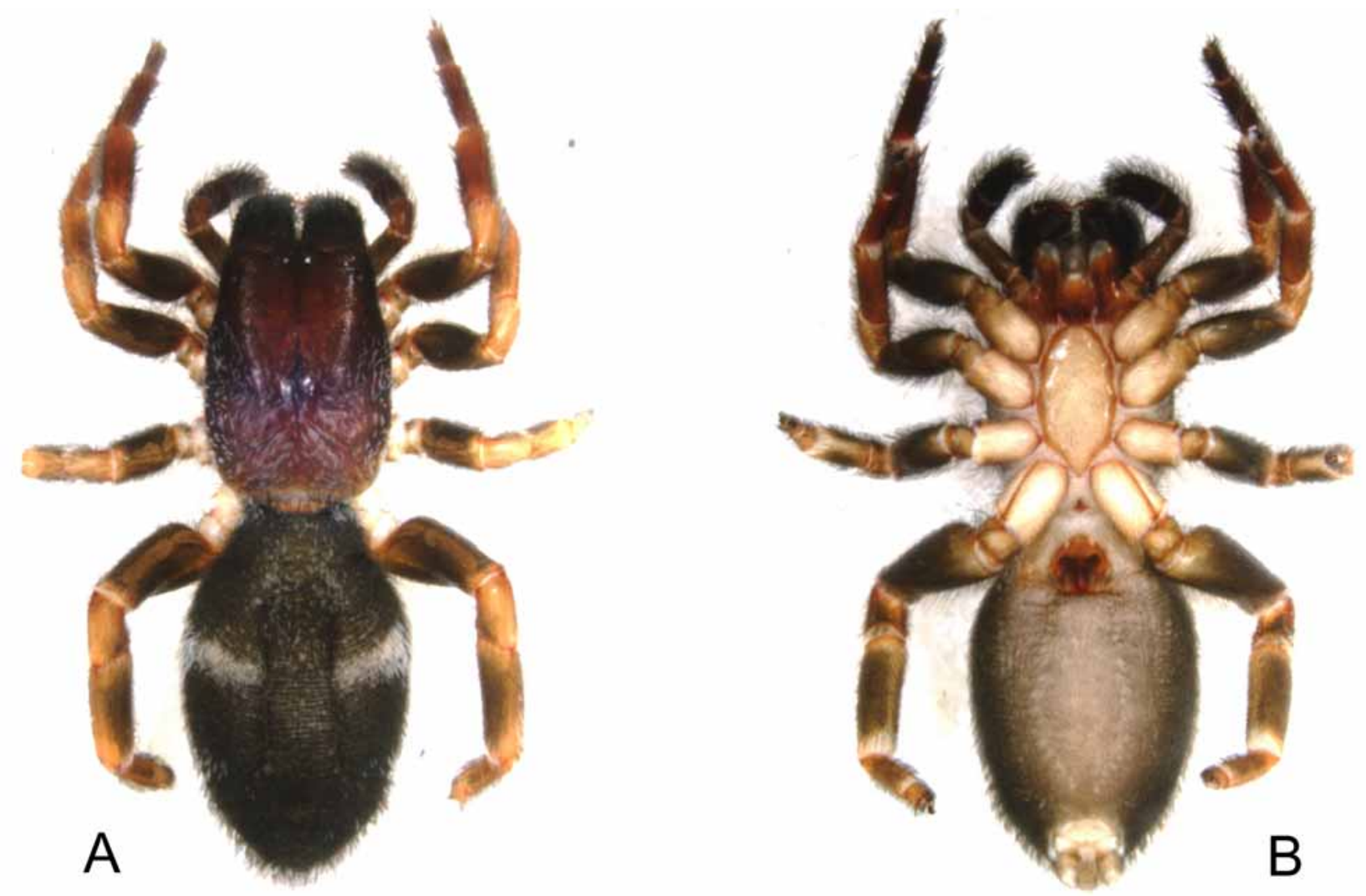

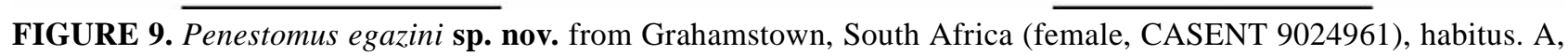
dorsal view; B, ventral view. Scale bars $=0.3 \mathrm{~mm}$. 


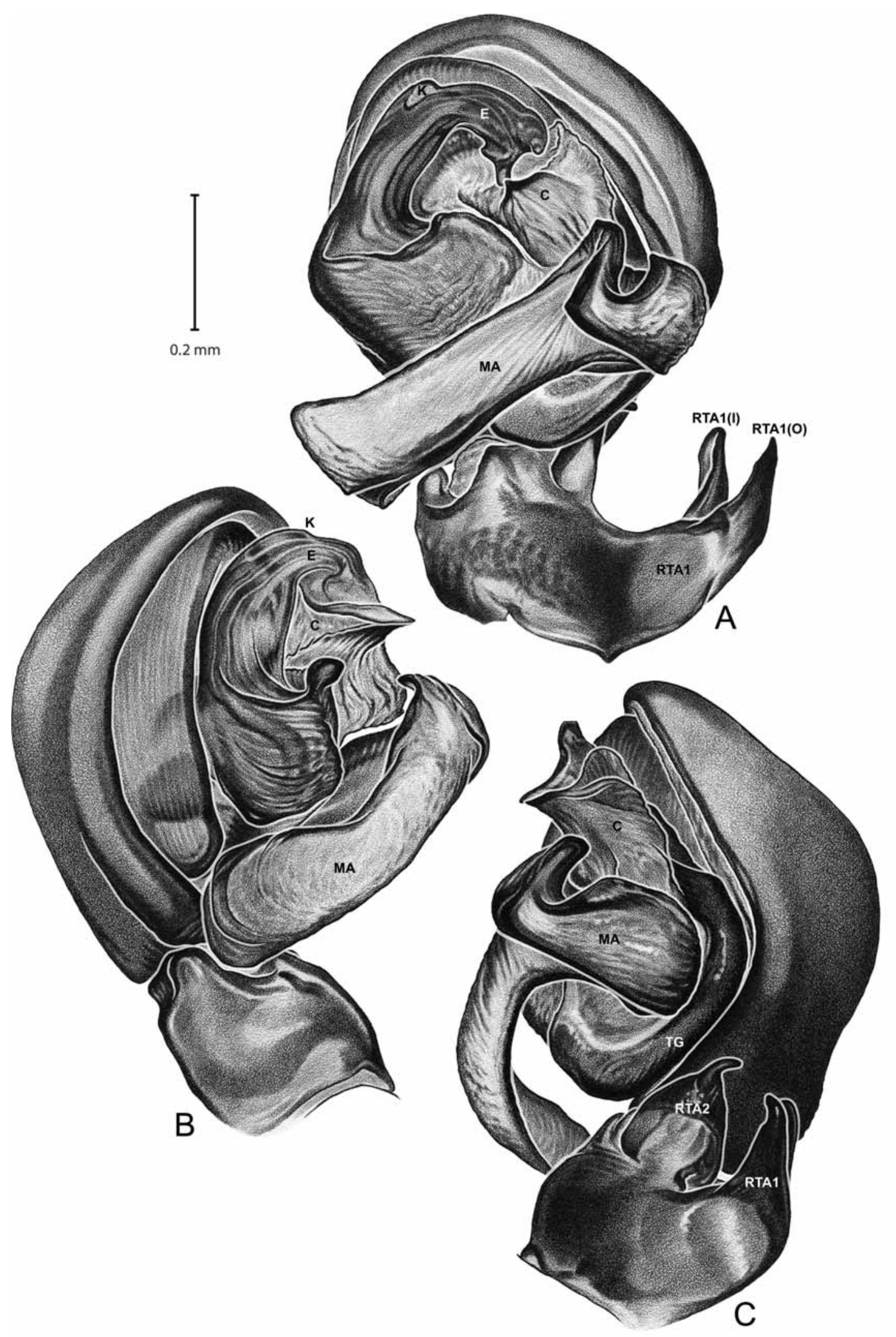

FIGURE 10. Penestomus egazini sp. nov. from Grahamstown, South Africa (male, CASENT 9024985), left pedipalp. A, ventral view; B, prolateral view; $C$, retrolateral view. Scale bars $=0.2 \mathrm{~mm}$. C, conductor; E, embolus; K, keel on embolus; MA, median apophysis; RTA1, outer, bifid ramus of retrolateral tibial apophysis; RTA1(I), inner tip of outer ramus of retrolateral tibial apophysis; RTA1 $(\mathrm{O})$, outer tip of outer ramus of retrolateral tibial apophysis; RTA2, inner ramus of retrolateral tibial apophysis; TG, tegulum. 


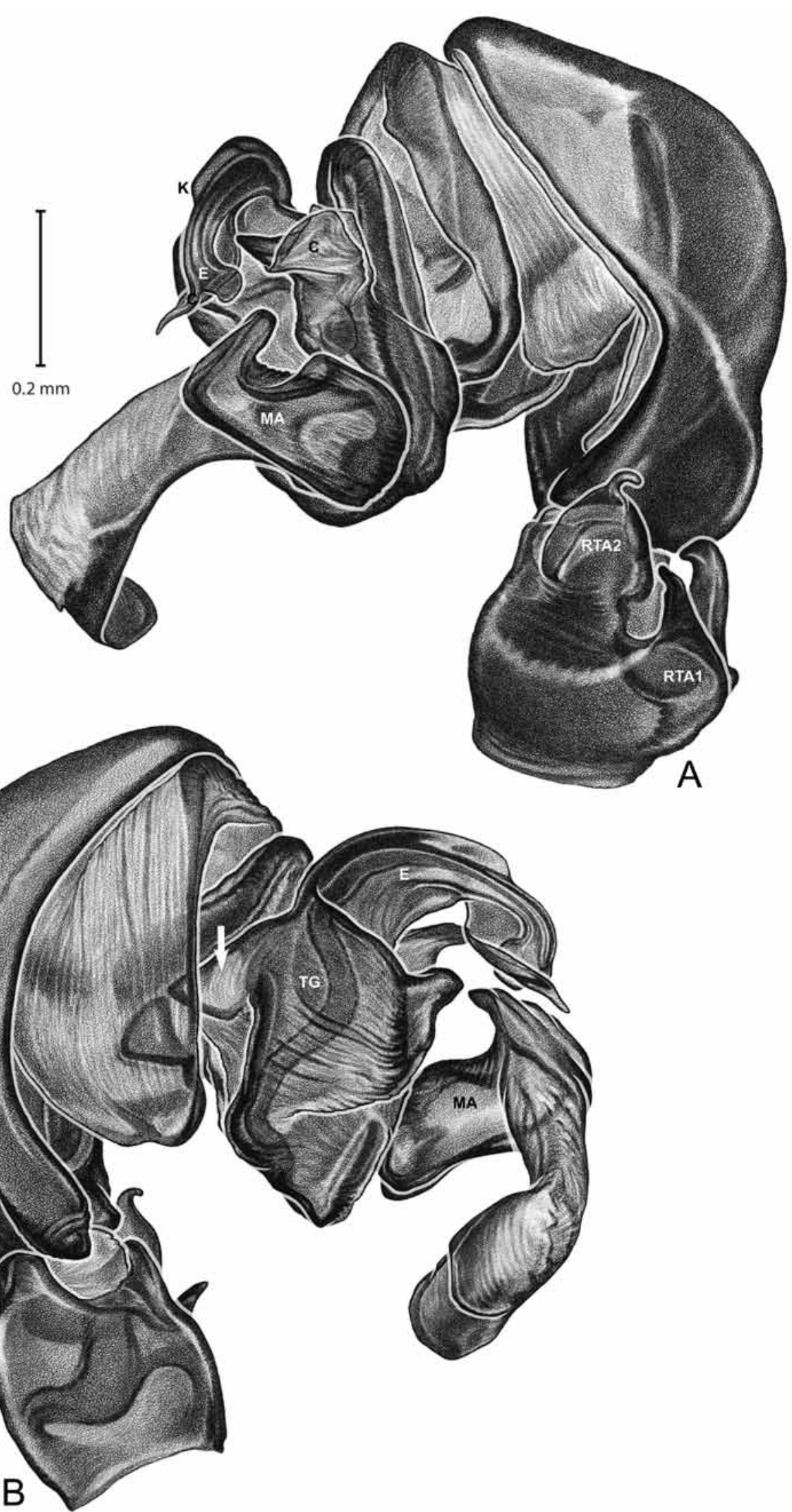

FIGURE 11. Penestomus egazini sp. nov. from Grahamstown, South Africa (male, CASENT 9024985), left pedipalp, expanded. A, retrolateral view; B, prolateral view, arrow to conical lobe on tegulum. Scale bars $=0.2 \mathrm{~mm}$. C, conductor; E, embolus; K, keel on embolus; MA, median apophysis; RTA1, outer, bifid ramus of retrolateral tibial apophysis; RTA1(I), inner tip of outer ramus of retrolateral tibial apophysis; RTA1(O), outer tip of outer ramus of retrolateral tibial apophysis; RTA2, inner ramus of retrolateral tibial apophysis; TG, tegulum. 


\section{Penestomus montanus sp. nov.}

http://zoobank.org/urn:Isid:zoobank.org:act:5413BD60-C459-4606-BB30-5B8E1E16AA57

Figs 3A, 3C, 12C, 12D, 13, 14, 21

Penestomus sp. nov. 3: Miller et al., 2010, fig. 1F.

Type material. Holotype: + , near Ha Mphahama, Qacha's Nek Distr., Lesotho, 305.520'S, $28^{\circ} 35.746^{\prime} \mathrm{E}$, 1820 m, 9 November 2003, sandstone ridge under rocks in webs, C. Haddad (AcAT 2006/1534, NCA). Paratypes: $1 \hat{\partial}, 4$,, 4 juveniles, same data as holotype (AcAT 2006/1535, NCA). SOUTH AFRICA: Eastern Cape: 1 ㅇ, Qacha's Nek (Site No. 30) $30.16502^{\circ} \mathrm{S}, 28.62045^{\circ} \mathrm{E}, 1748 \mathrm{~m}, 28$ November 2005, grassland active ground searching, UKZN [University of KwaZulu Natal, Pietermaritzburg] staff (AcAT 2006/1538, MDTP 5192, NCA); 1 đ̆, same data (AcAT 2006/1547, MDTP 2082, NCA); 1 juvenile, same data (AcAT 2006/1542, MDTP 7053, NCA); 1 \&, 1 juvenile, Qacha's Nek (Site No. 33) 30.15118 $\mathrm{S}, 28.62637^{\circ} \mathrm{E}$, $1829 \mathrm{~m}, 30$ November 2005, grassland active ground searching, UKZN staff (AcAT 2006/1541, MDTP 77378, NCA); 1 ㅇ, same data (AcAT 2006/1537, MDTP 5483, NCA); 1 , , Qacha's Nek (Site No. 36) $30.15538^{\circ} \mathrm{S}, 28.59319^{\circ} \mathrm{E}, 1692 \mathrm{~m}, 2$ December 2005 , grassland active ground searching, UKZN staff (AcAT 2006/1540, MDTP 5888, NCA); 1 juvenile, Prentjiesberg (Site No. 45) $31.1159^{\circ} \mathrm{S}, 28.1745^{\circ} \mathrm{E}, 1482 \mathrm{~m}, 10$ December 2005, grassland active ground searching, UKZN staff (AcAT 2006/1539, MDTP 78909, NCA); 1 o, Prentjiesberg (Site No. 46) $31.1159^{\circ} \mathrm{S}, 28.1745^{\circ} \mathrm{E}, 1491 \mathrm{~m}, 10$ December 2005, grassland active ground searching, UKZN staff (AcAT 2006/1536, MDTP 6743, NCA).
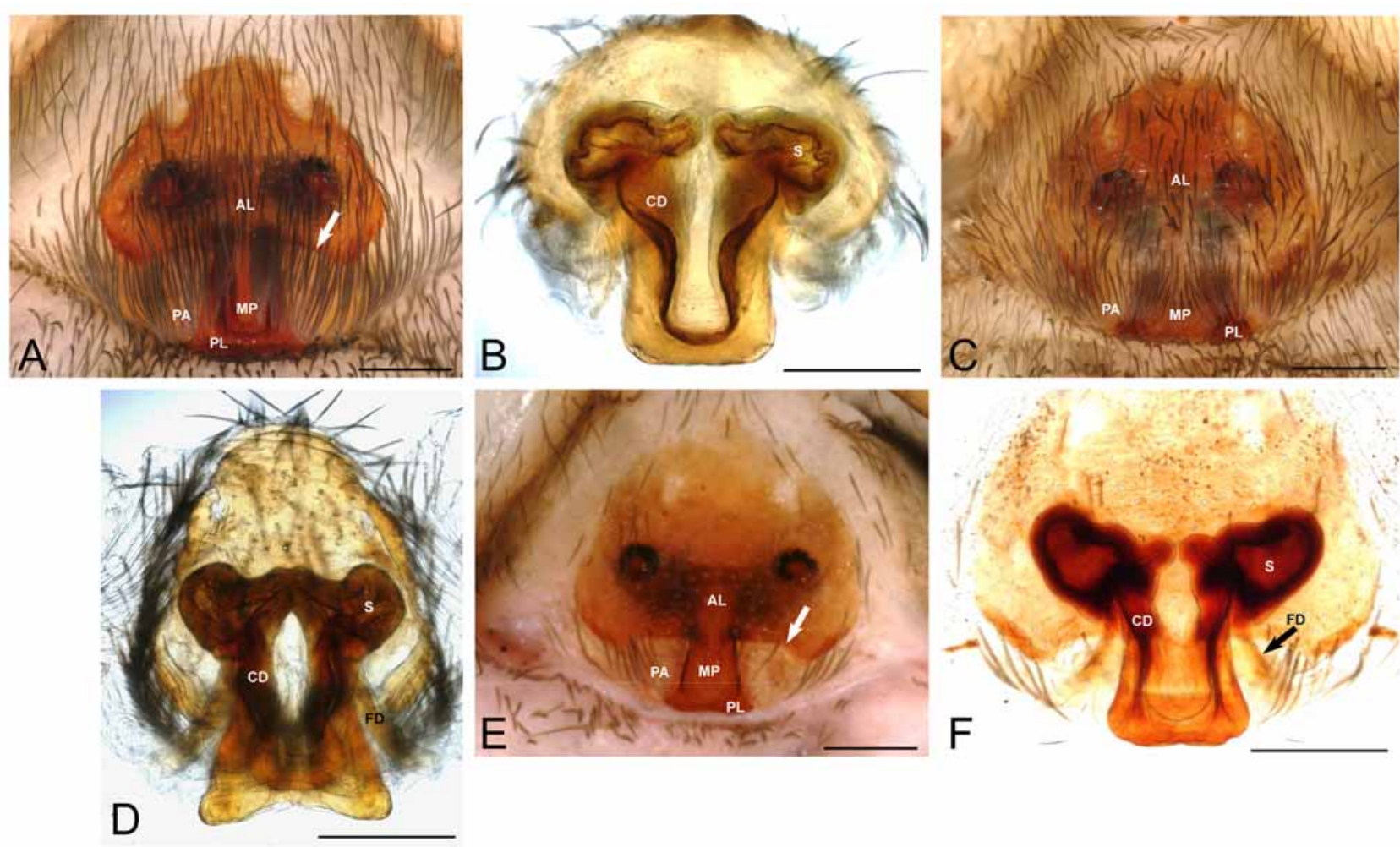

FIGURE 12. Epigynum of Penestomus species. A, B, P. egazini sp. nov. from Grahamstown, South Africa (CASENT 9024961), arrow indicates posterior margin of anterior lobe; C, D, P. montanus sp. nov. from Qacha's Nek, Lesotho (AcAT 2006/1535); E, F, P. prendinii sp. nov. from Beaufort West, South Africa, arrow indicates posterior margin of anterior lobe. A, C, E, ventral view; B, D, F, cleared, dorsal view. Scale bars $=0.2 \mathrm{~mm}$. AL, anterior lobe; CD, copulatory duct; FD, fertilization duct; MP, median projection of the AL; PA, posterolateral apophysis; PL, posterior lobe; S, spermatheca. 
Etymology. The specific epithet is Latin for from the mountains, named for the montane habitats in the uKhahlamba-Drakensberg and Maluti mountains in South Africa and Lesotho, respectively, to which the species is apparently endemic.

Diagnosis. Male distinguished by the distal part of RTA1, which has the bifid tips relatively short (Fig. 14A), longer in P. egazini and P. armatus (Fig. 10A). Further distinguished by the shape of the MA, which has a lobe on the anterior margin of the tail piece (Fig. 14A), absent from other species, and by the embolic tip, which is subrectangular and entire in P. montanus (Fig. 14A), bifid in other species (Fig. 10A).
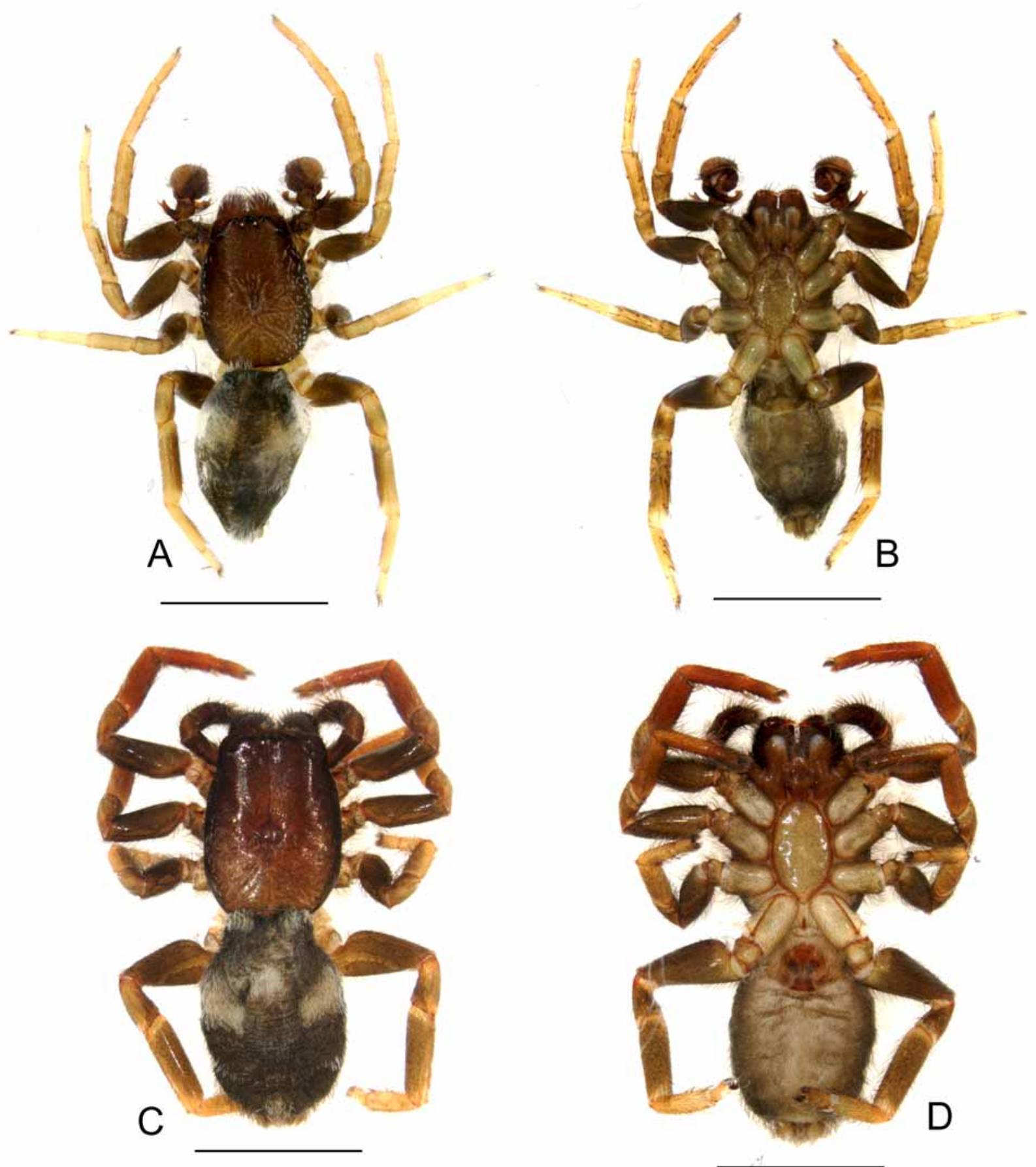

FIGURE 13. Penestomus montanus sp. nov. from Qacha's Nek, Lesotho (AcAT 2006/1535), habitus. A, B, male; C, D, female; A, C, dorsal view; B, D, ventral view. Scale bars $=0.2 \mathrm{~mm}$. 


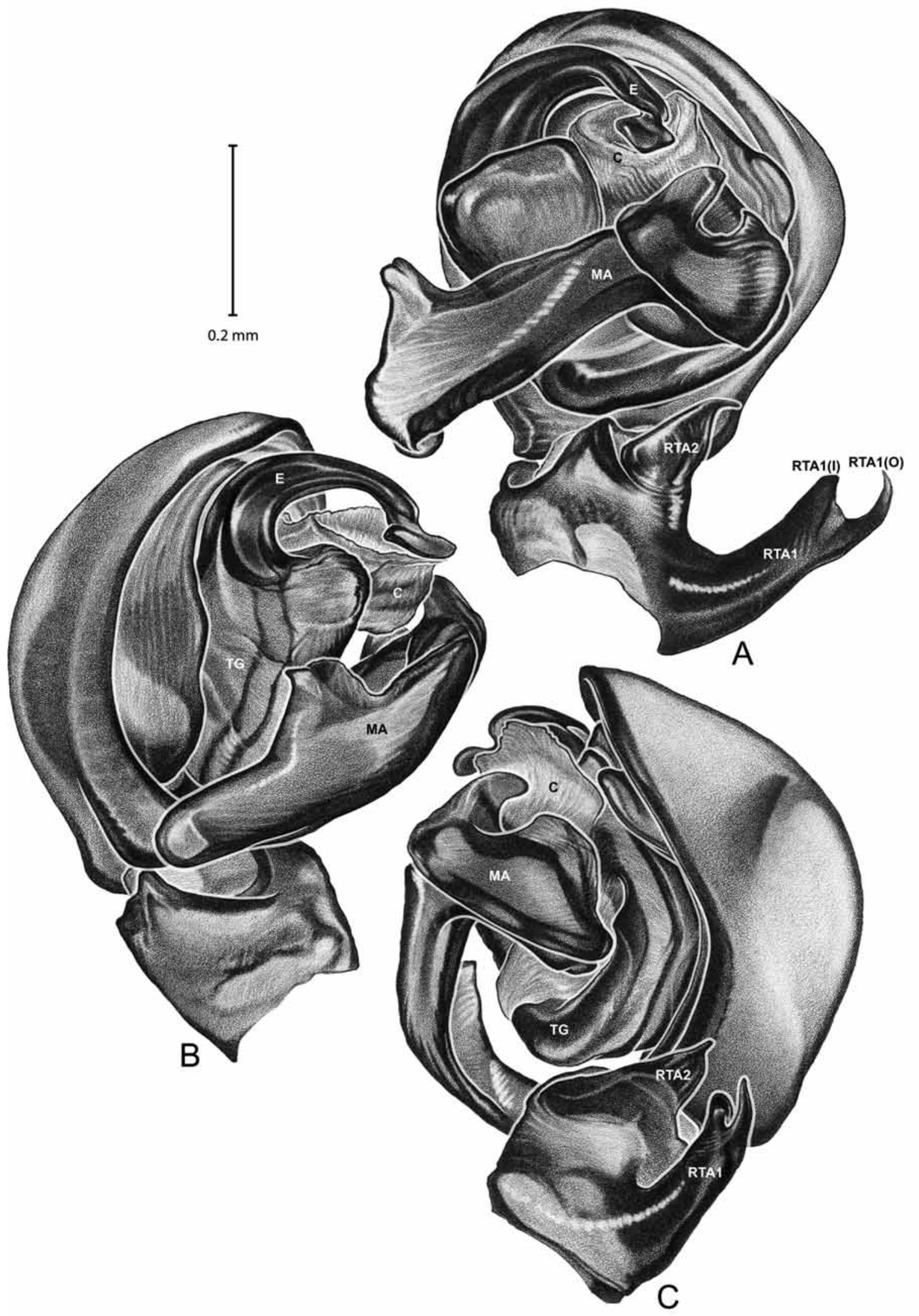

FIGURE 14. Penestomus montanus sp. nov. from Qacha's Nek, Lesotho (AcAT 2006/1535), left pedipalp. A, ventral view; B, prolateral view; C, retrolateral view. Scale bars $=0.2 \mathrm{~mm}$. C, conductor; E, embolus; MA, median apophysis; RTA1, outer, bifid ramus of retrolateral tibial apophysis; RTA1(I), inner tip of outer ramus of retrolateral tibial apophysis; RTA1(O), outer tip of outer ramus of retrolateral tibial apophysis; RTA2, inner ramus of retrolateral tibial apophysis; TG, tegulum. 
Female distinguished from other planus group species except $P$. prendinii sp. nov. by the grooves on the PL, which diverge posteriorly (Fig. 12C); other species except $P$. prendinii sp. nov. have the grooves nearly parallel (Fig. 8A). Distinguished from $P$. prendinii sp. nov. by the posterior margin of the AL, which is straight medially, then turns sharply to form lateral corners that project somewhat more posteriorly (Fig. 12E). The AL in P. montanus is unique among planus group species in being nearly oval in shape and weakly differentiated from the rest of the epigynum (Fig. 12C).

Description. Carapace brown, rugose, covered by fine black setae, with broad white setae concentrated in thoracic region, fovea round, shallow (Figs 13A, C). Sternum dusky pale yellow (Figs 13B, D). Chelicerae dark red-brown, with four promarginal teeth, two retromarginal teeth. Chelicerae with fine black setae, those of male with broad white setae in addition. Legs with broad white setae (more in male than female) and fine black setae. Tibiae with two rows of dorsal trichobothria, metatarsi with one distal trichobothrium. Legs brown basally, pale yellow distally. Abdomen dark gray dorsally with pair of light dorsolateral patches, covered with mixture of fine black and broad white setae (Figs 13A, C).

Male pedipalp: RTA1 with inside tip short and blunt, outside tip curved and pointed (Fig. 14A). Dorsal ridge short, restricted to base of RTA1. RTA2 with apex short, projecting distally (Fig. 14C). MA with anterior lobe arising from near distal part of tail (Fig. 14A). Embolus without keel on outer margin, distal region flat, subrectangular, not bifid (Figs 14A, B).

Epigynum: AL suboval, weakly differentiated from surrounding cuticle; PL approximately 1/4 length of epigynum, with grooves diverging posteriorly (Fig. 12C).

Male macrosetae: Leg I: femur d1, tibia r2-2-2, v1-2-2, metatarsus r1-1, v2-2-2; leg II: femur d1, tibia $\mathrm{p}$ 1-1-2, r1, v2-2-2, metatarsus r1, v2-2; leg III: femur d1, tibia r1, v2-2-2, metatarsus r1, v1-2; leg IV: femur d1, tibia v2-2-3-2, metatarsus v2-1-1-2, tarsus r1.

Female macrosetae: Leg I: femur d1, tibia v1-2-2, metatarsus v2-2-2; leg II: femur d1, tibia v1-2, metatarsus v2-2; leg III: femur d1, tibia v2, metatarsus v2; leg IV: femur d1, tibia v2, metatarsus v1-1-1-1-2, tarsus r1.

Paratype male (AcAT 2006/1535): Total length 4.0, carapace 1.84 long, 1.34 wide, 0.45 high, sternum 1.03 long, 0.63 wide. Leg measurements:

$\begin{array}{lcccc} & \text { I } & \text { II } & \text { III } & \text { IV } \\ \text { Femur } & 1.03 & 0.64 & 0.84 & 1.16 \\ \text { Patella } & 0.54 & 0.30 & 0.41 & 0.59 \\ \text { Tibia } & 0.79 & 0.70 & 0.56 & 0.94 \\ \text { Metatarsus } & 0.85 & 0.78 & 0.60 & 0.77 \\ \text { Tarsus } & \underline{0.43} & \underline{0.37} & \underline{0.27} & \underline{0.30} \\ \text { Total } & \mathbf{3 . 6 4} & \mathbf{2 . 7 9} & \mathbf{2 . 6 8} & \end{array}$

Paratype female (AcAT 2006/1535): Total length 4.1, carapace 1.8 long, 1.5 wide, 0.3 high, sternum 1.1 long, 0.6 wide. Leg measurements:

$\begin{array}{lccccc} & \text { I } & \text { II } & \text { III } & \text { IV } & \text { Pedipalp } \\ \text { Femur } & 1.03 & 0.96 & 0.78 & 1.17 & 0.59 \\ \text { Patella } & 0.59 & 0.56 & 0.44 & 0.63 & 0.25 \\ \text { Tibia } & 0.70 & 0.63 & 0.48 & 0.98 & 0.24 \\ \text { Metatarsus } & 0.75 & 0.67 & 0.46 & 0.73 & - \\ \text { Tarsus } & \underline{0.34} & \underline{0.30} & \underline{0.22} & \underline{0.27} & \underline{0.48} \\ \text { Total } & \mathbf{3 . 4 0} & \underline{\mathbf{3 . 1 3}} & \mathbf{2 . 3 9} & \mathbf{3 . 7 9} & \mathbf{1 . 5 5}\end{array}$

Natural history. This species occupies a relatively narrow altitudinal range (collected between 1480 $1830 \mathrm{~m}$ ), which coincides with sandstone rock formations. Above $2000 \mathrm{~m}$ sandstone is virtually absent, and granite and basalt formations dominate. The specimens from Ha Mphahama were collected on a sandstone 
ridge and constructed their webs underneath rocks lying on the soil surface. The webs followed a winding path that varied from ca. $6 \mathrm{~cm}$ in early instar immatures to ca. $18 \mathrm{~cm}$ in one adult female. Prey remains included Formicidae, Curculionidae and small Gryllidae.

Distribution. Known from Eastern Cape Province, South Africa, and Lesotho (Fig. 21).

\section{Penestomus prendinii sp. nov.}

http://zoobank.org/urn:Isid:zoobank.org:act:D0EB5BA8-162C-40E2-8176-E0B62616DCAB

Figs 12E, 12F, 15A, 15B, 21

Penestomus sp. nov. 2: Miller et al., 2010. GenBank accession numbers FJ948972 (28S rDNA), FJ948888 and FJ948930 (18S rDNA), FJ949049 (Histone H3), FJ949012 (cytochrome oxidase I).

Type material. Holotype: $q$, site $65,37.4 \mathrm{~km}$ NE Beaufort West, top of De Jager's Pass, Beaufort West

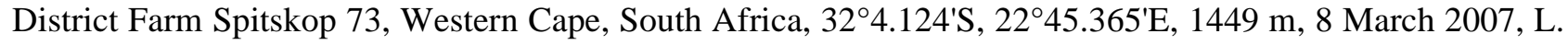
Prendini \& H. Bichard (AMNH). Paratypes: 2 , 4 juveniles, same data as holotype (AMNH).

Etymology. The specific epithet is a patronymic in honor of co-collector Lorenzo Prendini for his contributions to arachnid systematics in South Africa and elsewhere, and for braving gunfire during the collection of this species.

Diagnosis. Female distinguished by the shape of the carapace, which is more rounded laterally (Fig. 15A), nearly parallel sided in other species (Fig. 9A), and also flatter than other species. Female further distinguished from other planus group species by the shape of the posterior margin of the AL of the epigynum, which is straight medially, then turns sharply to form lateral corners that project somewhat more posteriorly (Fig. 12E). The posterior margin of the AL is distinctly recurved in other species (Fig. 12A) except P. montanus, which has an indistinct margin (Fig. 12C). Male unknown.

Description. Carapace brown, lateral margins somewhat rounded, covered by fine black setae, with broad white setae concentrated posterior to fovea (Fig. 15A). Sternum dusky pale yellow (Fig. 15B). Chelicerae brown, with five promarginal teeth, two retromarginal teeth; with fine black setae only. Legs dusky brown basally, anterior legs orange distally, posterior legs yellow distally. Abdomen dark gray dorsally with pair of broad light dorsolateral patches, covered with mixture of fine black and broad white setae (Fig. 15A).

Epigynum: AL subtriangular, clearly differentiated from surrounding cuticle, posterior margin straight medially, then turns sharply to form lateral corners projecting somewhat more posteriorly; PL approximately $1 / 4$ length of epigynum, grooves slightly diverging posteriorly (Fig. 12E).

Female macrosetae: Leg I: tibia v1-2-2, metatarsus v2-2-2; leg II: tibia v1, metatarsus v2-2-2; leg III: metatarsus v1-2; leg IV: metatarsus v2-1-2, tarsus r1.

Paratype female (AMNH): Total length 5.7, carapace 2.31 long, 1.88 wide, 0.16 high, sternum 1.34 long, 0.69 wide. Leg measurements:

\begin{tabular}{|c|c|c|c|c|c|}
\hline & I & II & III & IV & Pedipalp \\
\hline Femur & 1.33 & 1.31 & 0.98 & 1.58 & 0.68 \\
\hline Patella & 0.70 & 0.67 & 0.52 & 0.76 & 0.29 \\
\hline Tibia & 0.84 & 0.83 & 0.62 & 1.31 & 0.25 \\
\hline Metatarsus & 0.86 & 0.79 & 0.55 & 0.86 & - \\
\hline Tarsus & $\underline{0.39}$ & $\underline{0.34}$ & $\underline{0.24}$ & $\underline{0.29}$ & $\underline{0.46}$ \\
\hline Total & 4.12 & 3.94 & 2.91 & 4.81 & 1.69 \\
\hline
\end{tabular}

Distribution. Known from Western Cape Province, South Africa (Fig. 21). 

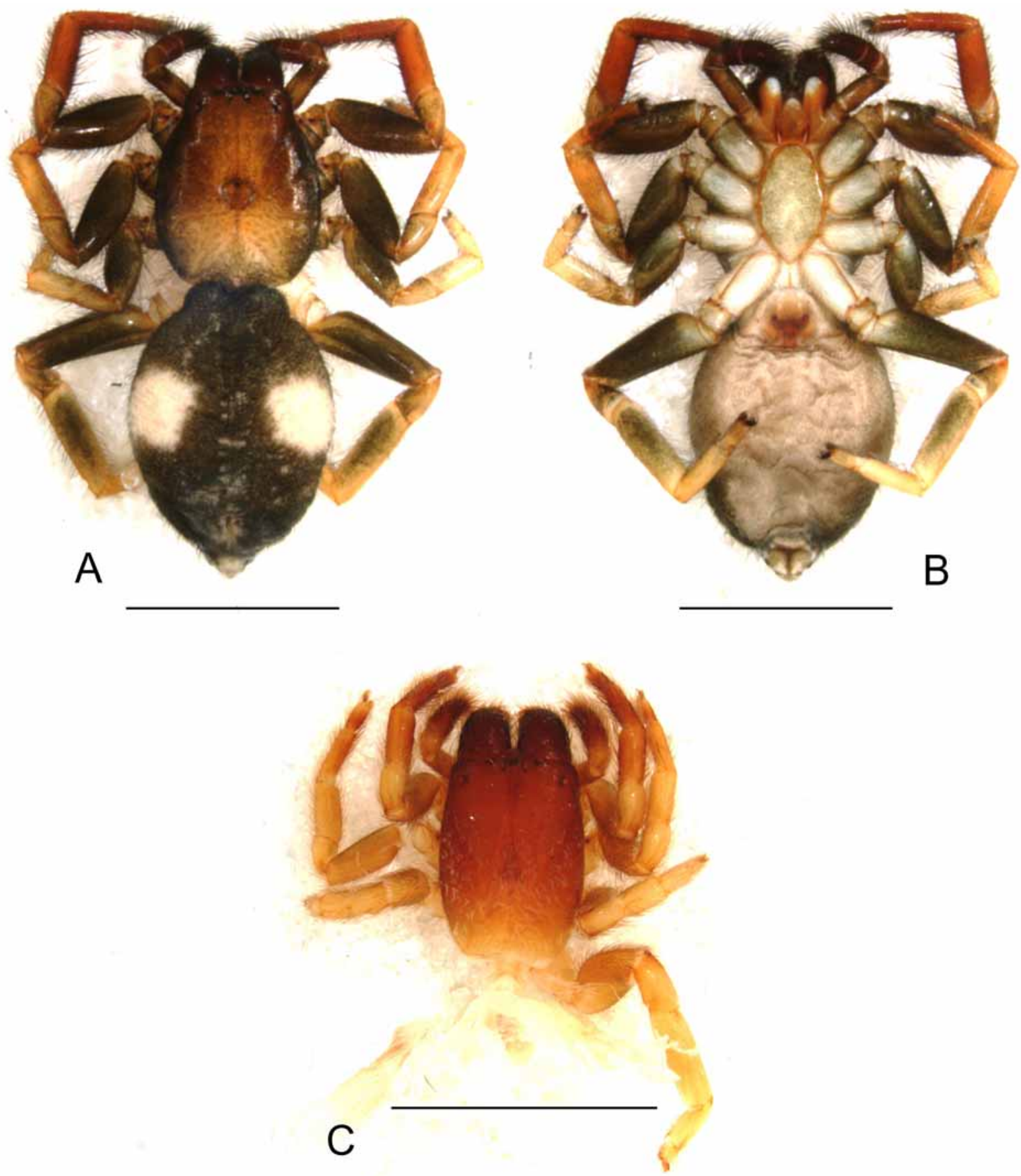

FIGURE 15. Habitus images of female Penestomus species. A, B, P. prendinii sp. nov. from Beaufort West, South Africa; C, P. planus Simon,1902 from Willowmore, South Africa (holotype). A, C, dorsal view; B, ventral view. Scale bars $=0.3 \mathrm{~mm}$.

\section{Penestomus planus Simon, 1902}

Figs 15C, 16A, 21

Penestomus planus Simon, 1902: 241; Lehtinen, 1967: 462, fig. 469; Dippenaar-Schoeman, 1989: 133 , fig. 6.

Type material. Holotype: ${ }^{\text {, }}$, Willowmore, Eastern Cape, South Africa $\left[33^{\circ} 10^{\prime}\right.$ S, $\left.23^{\circ} 21^{\prime} \mathrm{E}\right]$, D.H. Brauns (AR 14375, 21716, MNHN). 
Additional material examined. SOUTH AFRICA: Eastern Cape: 1 , Dunbrody, Uitenhage District

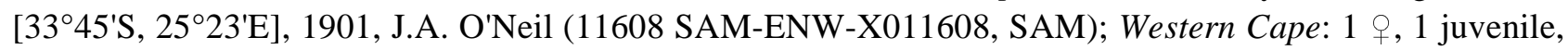

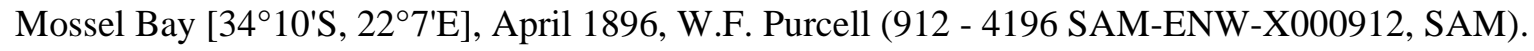

Diagnosis. Female distinguished from other planus group species as follows: from $P$. montanus by the parallel grooves on the PL (Figs 16A, B; diverging in P. montanus, Fig. 12C), and by the having the AL of the epigynum well defined and subtriangular (suboval and weakly defined in $P$. montanus, Fig. 12C); from $P$. egazini by the PL, which is approximately one third the length of the epigynum (Figs 16A, B; nearly half the length of the epigynum in P. egazini, Fig. 12A); from P. prendinii by the recurved posterior margin of the AL (Figs 16A, B; transverse medially in $P$. prendinii, Fig. 12E); from $P$. zulu sp. nov. by the lack of an invagination on the posterior margin of the PL (Fig. 16D); and from P. kruger sp. nov. by the overall shape of the epigynum, which is relatively wide and short with a strongly concave posterior margin of the AL in $P$. planus (Fig. 16A; narrow and long with a more weakly concave posterior margin of the AL in $P$. kruger sp. nov., Fig. 16B). Male unknown.

Description. Specimen faded, carapace orange, lighter posteriorly with smooth texture, covered by fine black setae, with broad white setae concentrated in thoracic and fovea region (Fig. 15C). Sternum pale yellow. Chelicerae dark red, with six promarginal teeth, two retromarginal teeth. Legs dusky yellow basally, anterior legs orange distally, posterior legs yellow distally. Abdomen pale, but details obscured due to specimen damage.

Epigynum: AL subtriangular, clearly differentiated from surrounding cuticle, posterior margin strongly concave; PL approximately 1/3 length of epigynum, with parallel grooves (Fig. 16A).

Female macrosetae: Leg I: femur d1, tibia v1-2-2, metatarsus v1-2-2; leg II: femur d1, tibia v1, metatarsus v1-2; leg III: femur d1, metatarsus v2; leg IV: femur d1, metatarsus v1-2; tarsus r1.

Holotype female (AR 14375, 21716): Carapace 2.28 long, 1.61 wide, 0.56 high, sternum 1.31 long, 0.75 wide (abdomen disarticulated from prosoma so total length undetermined). Leg measurements:

\begin{tabular}{|c|c|c|c|c|c|}
\hline & I & II & III & IV & Pedipalp \\
\hline Femur & 0.98 & 0.95 & 0.78 & 1.22 & 0.60 \\
\hline Patella & 0.57 & 0.59 & 0.47 & 0.73 & 0.23 \\
\hline Tibia & 0.64 & 0.61 & 0.48 & 1.08 & 0.25 \\
\hline Metatarsus & 0.75 & 0.66 & 0.47 & 0.74 & - \\
\hline Tarsus & $\underline{0.37}$ & $\underline{0.33}$ & $\underline{0.22}$ & $\underline{0.26}$ & $\underline{0.51}$ \\
\hline Total & 3.31 & 3.14 & 2.42 & 4.03 & 1.60 \\
\hline
\end{tabular}

Distribution. Known from Eastern Cape Province and Western Cape Province, South Africa (Fig. 21).

\section{Penestomus kruger sp. nov.}

http://zoobank.org/urn:lsid:zoobank.org:act:27784A05-AC2B-4110-8EA3-E6EE1A9E77AC

Figs 16B, 17A, 17B, 21

Type material. Holotype: + , Mid Plateau, Kruger National Park [Limpopo], South Africa $\left[24^{\circ} \mathrm{S}, 31^{\circ} 30^{\prime} \mathrm{E}\right], 7$ April 1984, A. Leroy (AcAT 98/283, LR 1248, NCA). Paratypes: 1 +5 juveniles, same data as holotype (AcAT 98/283, LR 1248, NCA).

Etymology. The specific epithet is a noun in apposition, named for the type locality, Kruger National Park.

Diagnosis. Female distinguished from other planus group species as follows: from $P$. montanus by the parallel grooves on the PL (Figs 16A, B; diverging in P. montanus, Fig. 12C), and by the having the AL of the epigynum well defined and subtriangular (suboval and weakly defined in $P$. montanus, Fig. 12C); from $P$. egazini by the PL, which is approximately one third the length of the epigynum (Figs 16A, B; nearly half the length of the epigynum in P. egazini, Fig. 12A); from P. prendinii by the recurved posterior margin of the AL 
(Figs 16A, B; transverse medially in P. prendinii, Fig. 12E); from $P$. zulu sp. nov. by the lack of an invagination on the posterior margin of the PL (Fig. 16D); and from P. planus by the overall shape of the epigynum, which is narrow and long with a more weakly concave posterior margin of the AL in $P$. kruger (Fig. 16B; relatively wide and short with a strongly concave posterior margin of the AL in P. planus, Fig. 16A). Male unknown.

Description. Carapace red-brown, lighter posteriorly with smooth texture, covered by fine black setae; broad white setae mostly posterior to fovea (Fig. 17A). Sternum pale yellow (Fig. 17B). Chelicerae redbrown, with six promarginal teeth, two retromarginal teeth; with fine black setae only. Legs dusky orange basally, anterior legs red-orange distally, posterior legs orange distally. Abdomen dark gray dorsally with light dorsolateral patches, smaller light patches anteriorly and above spinnerets (Fig. 17A).

Epigynum: AL subtriangular, clearly differentiated from surrounding cuticle, posterior margin moderately concave; PL approximately 1/3 length of epigynym, with parallel grooves (Fig. 16B).
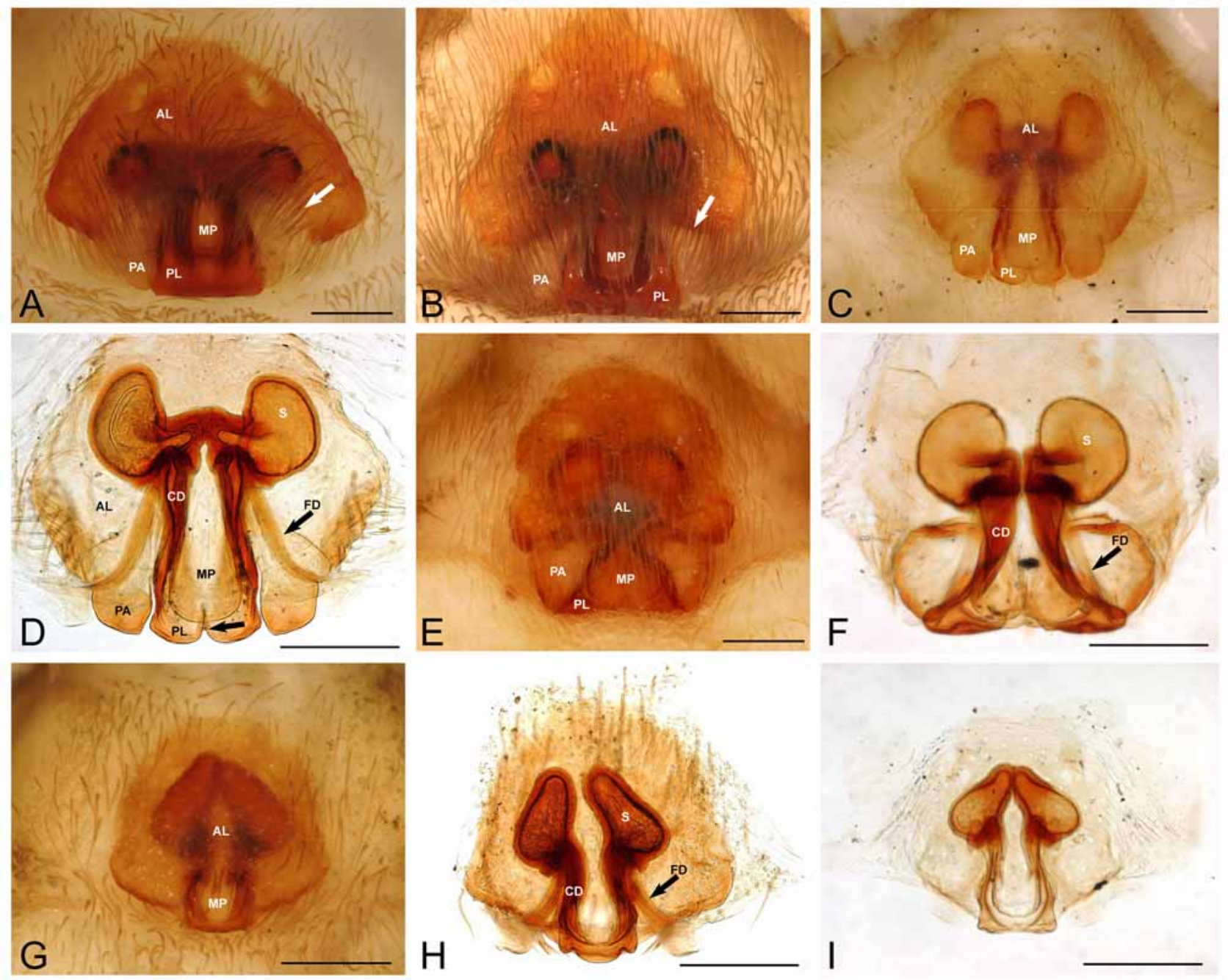

FIGURE 16. Epigynum of Penestomus species. A, P. planus Simon, 1902 from Willowmore, South Africa (AR 14375 , 21716), arrow indicates posterior margin of AL; B, P. kruger sp. nov. from Kruger National Park, South Africa (AcAT 98/283, LR 1248), arrow indicates posterior margin of AL; C, D, P. zulu sp. nov. from Mfongosi, KwaZulu Natal, South Africa (SAM-ENW-B004176), unlabeled arrow in D indicates invagination of posterior lobe; E, F, P. croeseri Dippenaar-Schoeman, 1989 from Grahamstown, South Africa (AcAT 87/249); G, H, P. stilleri (Dippenaar-Schoeman, 1989) from Winterhoek, South Africa (SAM-ENW-B002686); I, P. stilleri (Dippenaar-Schoeman, 1989) from Donkerkloof, South Africa (holotype, AcAT 88/29). A-C, E, G, ventral view; D, F, H, I, cleared, dorsal view. Scale bars $=0.2 \mathrm{~mm}$. AL, anterior lobe; $\mathrm{CD}$, copulatory duct; FD, fertilization duct; MP, median projection of the AL; PA, posterolateral apophysis; PL, posterior lobe; S, spermatheca. 
Female macrosetae: Leg I: femur d1, tibia v1-1-2, metatarsus v2-2-2; leg II: femur d1, tibia v1, metatarsus v2-2; leg III: femur d1, metatarsus v2; leg IV: femur d1, metatarsus v1-2; tarsus r1.

Holotype female (AcAT 98/283): Total length 6.1 carapace 2.56 long, 1.91 wide, 0.48 high, sternum 1.53 long, 0.80 wide. Leg measurements:

$\begin{array}{lccccc} & \text { I } & \text { II } & \text { III } & \text { IV } & \text { Pedipalp } \\ \text { Femur } & 1.27 & 1.30 & 1.05 & 1.58 & 0.79 \\ \text { Patella } & 0.69 & 0.71 & 0.60 & 0.84 & 0.31 \\ \text { Tibia } & 0.89 & 0.84 & 0.63 & 1.37 & 0.30 \\ \text { Metatarsus } & 0.86 & 0.84 & 0.60 & 0.94 & - \\ \text { Tarsus } & \underline{0.46} & \underline{0.43} & \underline{0.30} & \underline{0.43} & \underline{0.51} \\ \text { Total } & \mathbf{4 . 1 7} & \mathbf{4 . 1 3} & \mathbf{3 . 1 8} & \mathbf{5 . 1 5} & \mathbf{1 . 9 0}\end{array}$

Distribution. Known from Limpopo Province, South Africa (Fig. 21).

\section{Penestomus zulu sp. nov.}

http://zoobank.org/urn:lsid:zoobank.org:act:B04D9201-7E5A-450A-9F8F-51D7AFA48EC1

Figs 16C, 16D, 17C, 17D, 21

Type material. Holotype: ${ }_{+}$, Mfongosi, Zululand, KwaZulu Natal, South Africa [ $\left.27^{\circ} 17^{\prime} \mathrm{S}, 32^{\circ} 9^{\prime} \mathrm{E}\right]$, February 1918, W.E. Jones (B4176 SAM-ENW-B004176, SAM).

Etymology. The specific epithet is a noun in apposition derived from the collection locality and the dominant tribe in the region.

Diagnosis. Female distinguished by the median invagination in the posterior margin of the PL (Fig. 16D). Female further distinguished from other planus group species by the sclerotization of the PA (Fig. 16C), which is about the same as the AL (lighter in other planus group species, Fig. 16A). Male unknown.

Description. Carapace orange, lighter posteriorly with smooth texture, covered by fine black setae and broad white setae (Fig. 17A). Sternum pale yellow (Fig. 17B). Chelicerae red-brown, with five promarginal teeth, two retromarginal teeth. Legs dusky yellow, anterior legs orange distally. Abdomen dark gray dorsally with indistinct light dorsolateral patches (Fig. 17A).

Epigynum: AL nearly hexagonal, moderately differentiated from surrounding cuticle, broadly connected to PL; PL approximately 1/3 length of epigynum, with more or less parallel grooves (Fig. 16C), with median invagination on posterior margin (Fig. 16D). Sclerotization of PA undifferentiated from the rest of the epigynum, separated from AL by groove (Fig. 16C).

Female macrosetae: Leg I: femur d1, tibia v1-2, metatarsus v2-2; leg II: femur d1, metatarsus v2-2; leg III: femur d1, metatarsus v2; leg IV: femur d1, metatarsus v1-2; tarsus r1.

Holotype female (SAM-ENW-B004176): Total length 4.5, carapace 2.00 long, 1.39 wide, 0.44 high, sternum 1.11 long, 0.63 wide. Leg measurements:

$\begin{array}{lccccc} & \text { I } & \text { II } & \text { III } & \text { IV } & \text { Pedipalp } \\ \text { Femur } & 0.98 & 0.94 & 0.81 & 1.10 & 0.57 \\ \text { Patella } & 0.56 & 0.51 & 0.47 & 0.64 & 0.19 \\ \text { Tibia } & 0.63 & 0.55 & 0.46 & 0.91 & 0.21 \\ \text { Metatarsus } & 0.64 & 0.56 & 0.44 & 0.69 & - \\ \text { Tarsus } & \underline{0.32} & \underline{0.29} & \underline{0.18} & \underline{0.21} & \underline{0.44} \\ \text { Total } & \mathbf{3 . 1 3} & \mathbf{2 . 8 6} & \mathbf{2 . 3 7} & \mathbf{3 . 5 6} & \mathbf{1 . 4 2}\end{array}$

Distribution. Known from KwaZulu Natal Province, South Africa (Fig. 21). 

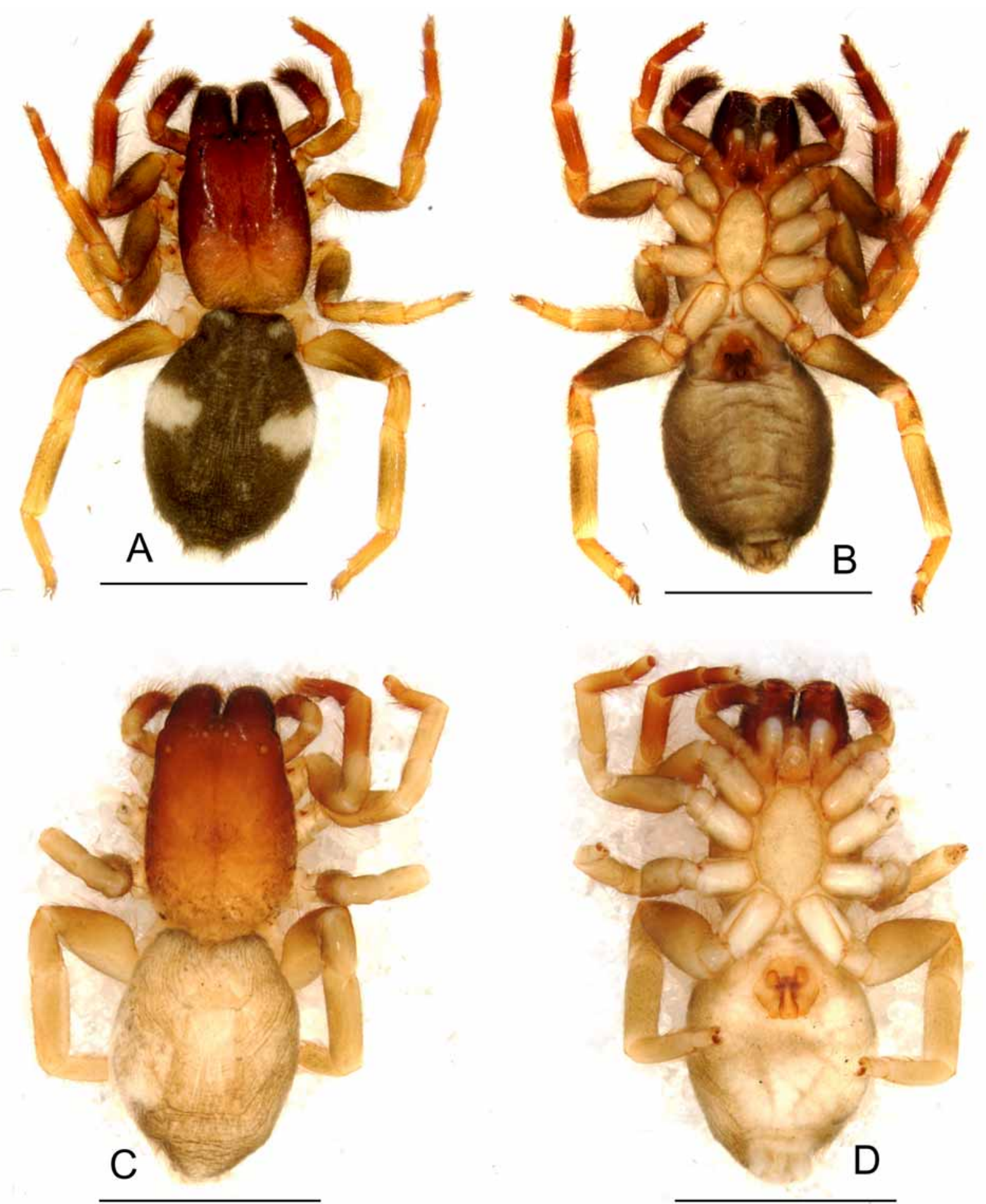

FIGURE 17.. Habitus images of female Penestomus species. A, B, P. kruger sp. nov. from Kruger National Park, South Africa (AcAT 98/283, LR 1248); C, D, Penestomus zulu sp. nov. from Mfangosi, KwaZulu Natal, South Africa (SAMENW-B004176); A, C, dorsal view; B, D, ventral view. Scale bars A, B $=0.3 \mathrm{~mm} ; \mathrm{C}, \mathrm{D}=0.2 \mathrm{~mm}$.

\section{Penestomus croeseri Dippenaar-Schoeman, 1989}

Figs 16E, 16F, 18A, 18B, 21

Penestomus croeseri Dippenaar-Schoeman, 1989: 132, figs 1, 3-5.

Type material. Holotype: $q$ (with 2 paratypes), Grahamstown [Eastern Cape], South Africa, $33^{\circ} 19^{\prime} \mathrm{S}$ $26^{\circ} 32^{\prime} \mathrm{E}, 500 \mathrm{~m}, 1$ January 1980, in riverine bush from soil surface, P. Croeser, P. Hawkes (AcAT 87/249, 
NCA). Paratypes: + , same data as holotype (AcAT 87/249a, NCA); + , same data as holotype (AcAT 87/ 249b, NCA).

Diagnosis. Female distinguished by the narrow connection between the AL and the MP, which then becomes a wide plate with convex lateral margins (Fig. 16E). Male unknown.

Description. Carapace red-brown, lighter posteriorly with smooth texture, with sparse fine black setae and broad white setae mostly at margin and fovea region (Fig. 18A). Sternum dusky pale yellow (Fig. 18B). Chelicerae red-brown, with six promarginal teeth, three retromarginal teeth; with fine black setae only. Legs brown basally, anterior legs red-brown distally, posterior legs pale yellow distally. Abdomen medium gray dorsally without light dorsolateral patches, covered by fine black setae, broad white setae around margin (Fig. 18A).
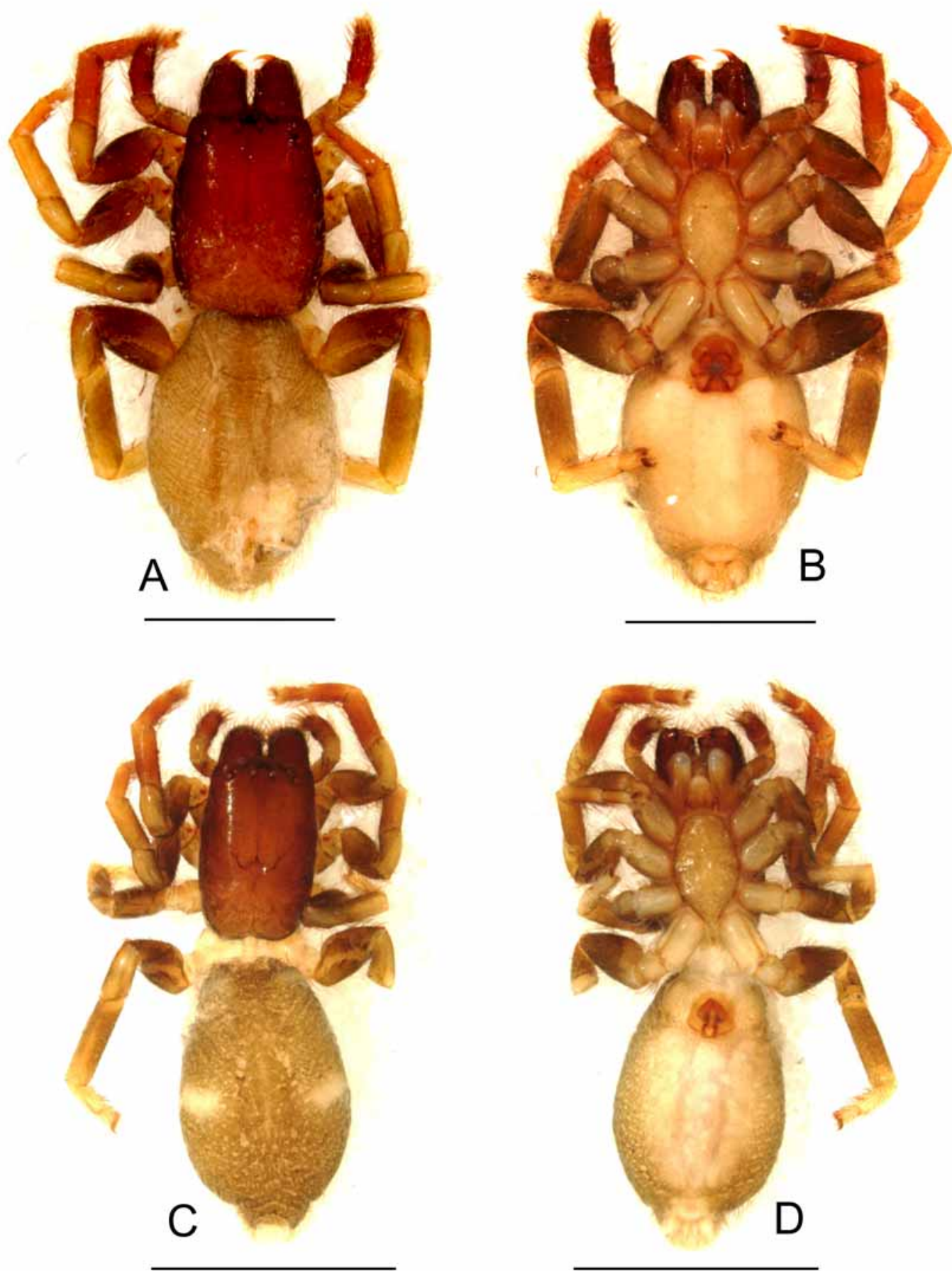

FIGURE 18. Habitus images of female Penestomus species. A, B, P. croeseri Dippenaar-Schoeman, 1989 from Grahamstown, South Africa (AcAT 87/249). C, D, P. stilleri (Dippenaar-Schoeman, 1989) from Winterhoek, South Africa (SAM-ENW-B002686). A, C, dorsal view; B, D, ventral view. Scale bars $=0.2 \mathrm{~mm}$. 
Epigynum: Subpentagonal, clearly differentiated from surrounding cuticle. AL a half oval, connected to MP by narrow waist; MP a wide plate with convex lateral margins; MP/PL complex approximately $1 / 3$ length of epigynum, much wider posteriorly than anteriorly. PA only marginally less sclerotized than the rest of the epigynum, separated from AL by groove (Fig. 16E).

Female macrosetae: Leg I: femur d1, tibia v1-2, metatarsus v1-2-2; leg II: femur d1, tibia v1, metatarsus v1-2; leg III: femur d1, tibia v1, metatarsus v1-2; leg IV: femur d1, metatarsus v1-2; tarsus r1.

Paratype female (AcAT 87/249): Total length 5.0, carapace 2.13 long, 1.59 wide, 0.53 high, sternum 1.25 long, 0.72 wide. Leg measurements:

$\begin{array}{lccccc} & \text { I } & \text { II } & \text { III } & \text { IV } & \text { Pedipalp } \\ \text { Femur } & 1.14 & 1.08 & 0.86 & 1.30 & 0.62 \\ \text { Patella } & 0.59 & 0.54 & 0.51 & 0.70 & 0.22 \\ \text { Tibia } & 0.75 & 0.70 & 0.56 & 1.10 & 0.25 \\ \text { Metatarsus } & 0.75 & 0.67 & 0.51 & 0.78 & - \\ \text { Tarsus } & \underline{0.37} & \underline{0.30} & \underline{0.19} & \underline{0.24} & \underline{0.48} \\ \text { Total } & \mathbf{3 . 5 9} & \mathbf{3 . 2 9} & \mathbf{2 . 6 2} & \mathbf{4 . 1 1} & \mathbf{1 . 5 7}\end{array}$

Distribution. Known from Eastern Cape Province, South Africa (Fig. 21).

\section{Penestomus stilleri (Dippenaar-Schoeman, 1989), new combination}

Figs 8E, 8F, 16G-I, 18C, 18D, 21

Wajane stilleri Dippenaar-Schoeman, 1989: 134, figs 2, 7-8.

Type material. Holotype: $q$ (with 1 juvenile paratype), Paarl Du Toit's Kloof, Donkerkloof, Western Cape, South Africa, $33^{\circ} 45^{\prime} \mathrm{S} 18^{\circ} 50^{\prime} \mathrm{E}, 300 \mathrm{~m}, 3$ August 1975, found in silk-lined tunnels under exfoliated section of rock, in a boulder, M. Stiller (AcAT 88/29, NCA).

Additional material examined. SOUTH AFRICA. Western Cape: 3 \& 5 juveniles, Winterhoek $\left[33.1^{\circ} \mathrm{S}\right.$, $19.13^{\circ} \mathrm{E}$ ] 4400-5500 ft, 20 November 1916, Tucker (B2686 SAM-ENW-B002686, SAM); 2 , 1 juvenile, Winterhoek [33. $\left.1^{\circ} \mathrm{S}, 19.13^{\circ} \mathrm{E}\right], 5000-5600 \mathrm{ft}, 20$ November 1916, Tucker (B2853 SAM-ENW-B002853, SAM).

Diagnosis. Female distinguished by the ovoid, diverging spermathecae (Figs 16H, I) and PA of the epigynum that are as sclerotized as the AL (Figs 8E, 16G). Male unknown.

Description. Carapace orange-yellow, lighter posteriorly with smooth texture (Fig. 18C). Sternum dusky pale yellow (Fig. 18D). Chelicerae orange, with five promarginal teeth, two retromarginal teeth. Legs brown basally, leg I and II orange distally, posterior legs pale yellow distally. Abdomen medium gray dorsally with light dorsolateral patches (Fig. 18C). (Most setae lost on specimens so these data are not reported here.)

Epigynum: Subpentagonal, MP/PL complex approximately 1/4 length of epigynum, parallel sided with grooves converging posteriorly, extending only slightly posterior from AL (Figs 8E, 16G). PA sclerotized, undifferentiated from rest of epigynum.

Female macrosetae: Leg I: femur d1, tibia v2-2, metatarsus v2-2-2; leg II: femur d1, tibia v1, metatarsus v2-2; leg III: femur d1, tibia v1, metatarsus v1-3; leg IV: femur d1, metatarsus v1-1-3.

Holotype female (AcAT 88/29): Total length 3.6, carapace 1.44 long, 0.97 wide, 0.38 high, sternum 0.91 long, 0.50 wide. Leg measurements:

$\begin{array}{lccccc} & \text { I } & \text { II } & \text { III } & \text { IV } & \text { Pedipalp } \\ \text { Femur } & 0.65 & 0.62 & 0.56 & 0.71 & 0.35 \\ \text { Patella } & 0.43 & 0.40 & 0.32 & 0.48 & 0.17 \\ \text { Tibia } & 0.48 & 0.44 & 0.40 & 0.63 & 0.17 \\ \text { Metatarsus } & 0.43 & 0.40 & 0.33 & 0.46 & - \\ \text { Tarsus } & \underline{0.27} & \underline{0.24} & \underline{0.19} & \underline{0.22} & \underline{0.30} \\ \text { Total } & \mathbf{2 . 2 5} & \mathbf{2 . 1 0} & \mathbf{1 . 7 9} & \mathbf{2 . 5 1} & \mathbf{1 . 0 0}\end{array}$


Distribution. Known from Western Cape Province, South Africa (Fig. 21).

Remarks. Dippenaar-Schoeman (1989) reported the absence of a cribellum in this species. Indeed, no cribellum is obvious in the somewhat degraded type series specimens, although there is evidence of a broad lobe that could be a cribellum or wide colulus. In the holotype, most setae are missing from the legs, including the calamistrum region; in the juvenile paratype, both legs IV are broken near the tibia-metatarsus joint. Other specimens (i.e., those from Winterhoek, South Africa; B2853, SAM-ENW-B002853), have a well developed cribellum (Fig. 8F) and calamistrum.

\section{Penestomus armatus (Lehtinen, 1967), new combination}

Figs 3D, 19-21

Wajane armata Lehtinen, 1967: 409, figs 470-471.

Type material. Holotype: ${ }^{\lambda}$, Alicedale, Eastern Cape, South Africa $\left[33^{\circ} 16^{\prime} \mathrm{S}, 2^{\circ}{ }^{\prime}{ }^{\prime} \mathrm{E}\right]$, January 1916 , F. Cruden (MHNG).

Diagnosis. Male distinguished from P. egazini (Fig. 10A) by the absence of a keel on the outer margin of the embolus (Fig. 20A); and from P. montanus (Fig. 14A) by the lack of a lobe on the anterior margin of the tail of the MA (Fig. 20A). Male further distinguished by the relatively shallow notch in the retrolateral plate of the MA (Fig. 20C). Female unknown.

Description. Carapace orange, rugose (Fig. 19A; setae, if any, lost from holotype). Sternum pale yellow (Fig. 19B; damaged in holotype specimen). Chelicerae orange, with five promarginal teeth, two retromarginal teeth. Legs brown basally, pale yellow distally. Abdomen light gray dorsally with pair of light dorsolateral patches (Fig. 19A; setae, if any, lost from holotype).

Male pedipalp: RTA1 with tips long, diverging, inside tip curved ventrally, outside tip with basal suture (Fig. 20A). Dorsal ridge short, restricted to base of RTA1. RTA2 with apex short, curved dorsally (Fig. 20C). MA without anterior lobe arising from tail (Fig. 20A). Embolus without keel along outer margin; bifid distal region formed from small transparent dorsal process and pointed distal tip (Fig. 20C).
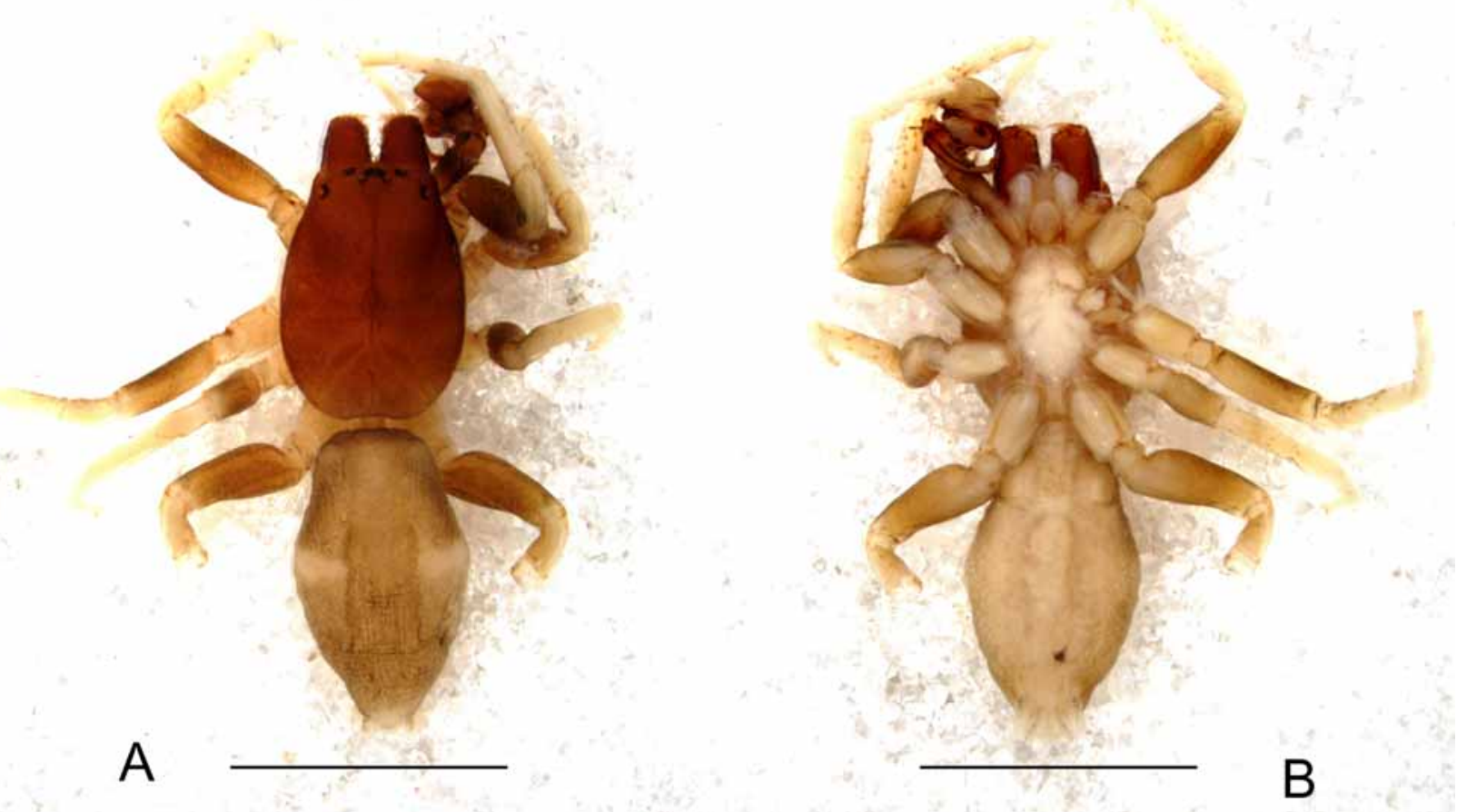

FIGURE 19. A, B, Habitus images of male Penestomus armatus (Lehtinen, 1967) from Alicedale, South Africa (holotype of Wajane armata). A, dorsal view; B, ventral view. Scale bars $=0.3 \mathrm{~mm}$. 


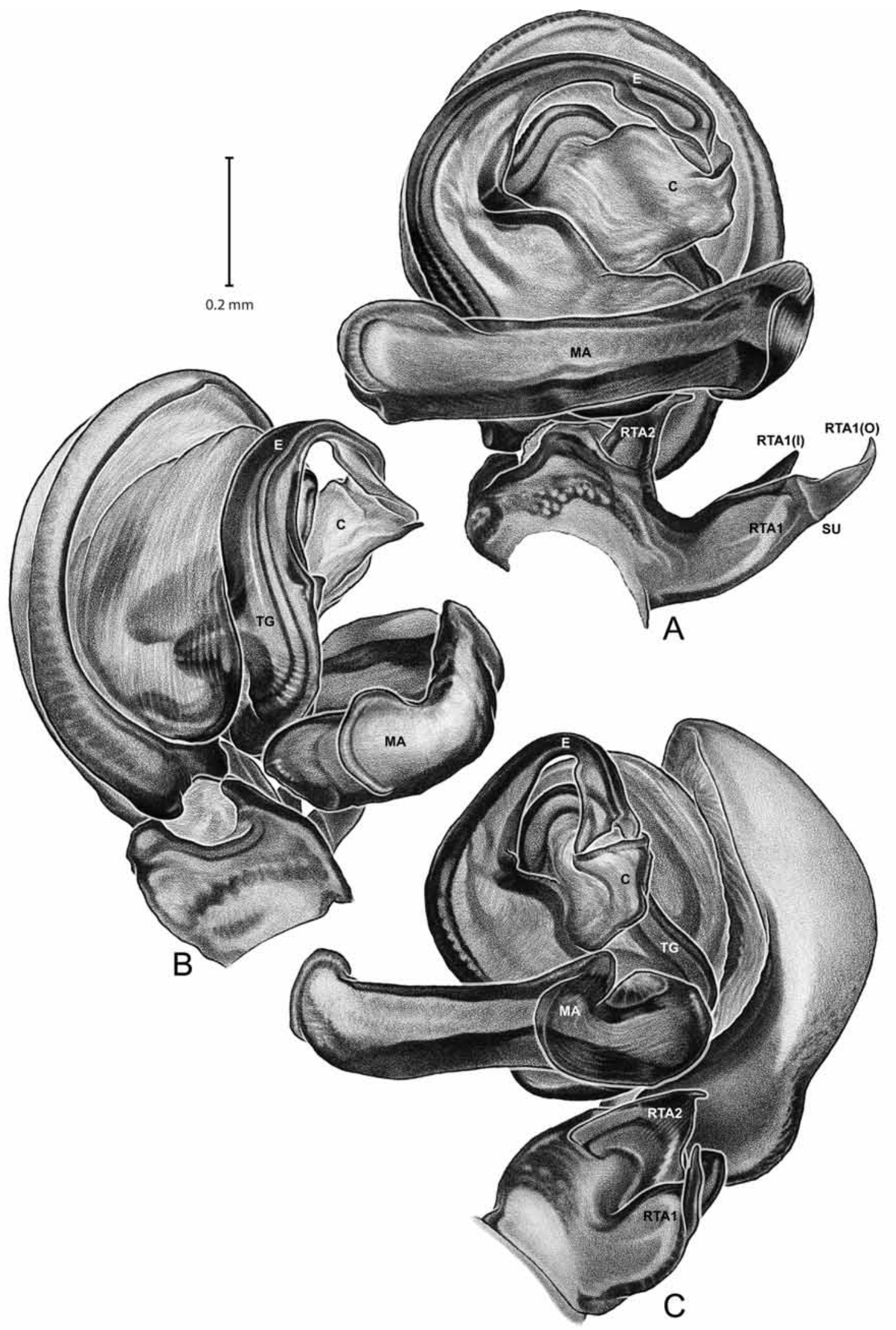

FIGURE 20. Penestomus armatus (Lehtinen, 1967) from Alicedale, South Africa (holotype of Wajane armata), left pedipalp. A, ventral view; B, prolateral view; C, retrolateral view. Scale bars $=0.2 \mathrm{~mm}$. C, conductor; E, embolus; MA, median apophysis; RTA1, outer, bifid ramus of retrolateral tibial apophysis; RTA1(I), inner tip of outer ramus of retrolateral tibial apophysis; RTA1(O), outer tip of outer ramus of retrolateral tibial apophysis; RTA2, inner ramus of retrolateral tibial apophysis; $\mathrm{SU}$, suture; TG, tegulum. 
Male macrosetae: Leg I: femur d1, tibia r2-2-2-2-2-1, v1-2-2, metatarsus r1-3-1, v2-2-2; leg II: femur d1, tibia r1-1-1, v2-2-2, metatarsus r1-1-1, v2-2; leg III: femur d1, tibia r1-1-1, v2-2-2, metatarsus r1-1-1, v2-2; leg IV: femur d1 (tibia, metatarsus, tarsus undetermined).

Holotype male: Total length 4.9, carapace 2.20 long, 1.56 wide, 0.56 high, sternum 1.28 long, 0.69 wide. Leg measurements:

$\begin{array}{lcccc} & \text { I } & \text { II } & \text { III } & \text { IV* } \\ \text { Femur } & 1.17 & 1.11 & 0.95 & 1.27 \\ \text { Patella } & 0.59 & 0.56 & 0.50 & 0.67 \\ \text { Tibia } & 0.91 & 0.80 & 0.64 & \text { NA } \\ \text { Metatarsus } & 1.02 & 0.88 & 0.69 & \text { NA } \\ \text { Tarsus } & \underline{0.51} & \underline{0.45} & \underline{0.36} & \underline{\mathbf{3 A}} \\ \text { Total } & \mathbf{4 . 2 0} & \mathbf{3 . 8 0} & & \end{array}$

Distribution. Known from Eastern Cape Province, South Africa (Fig. 21).

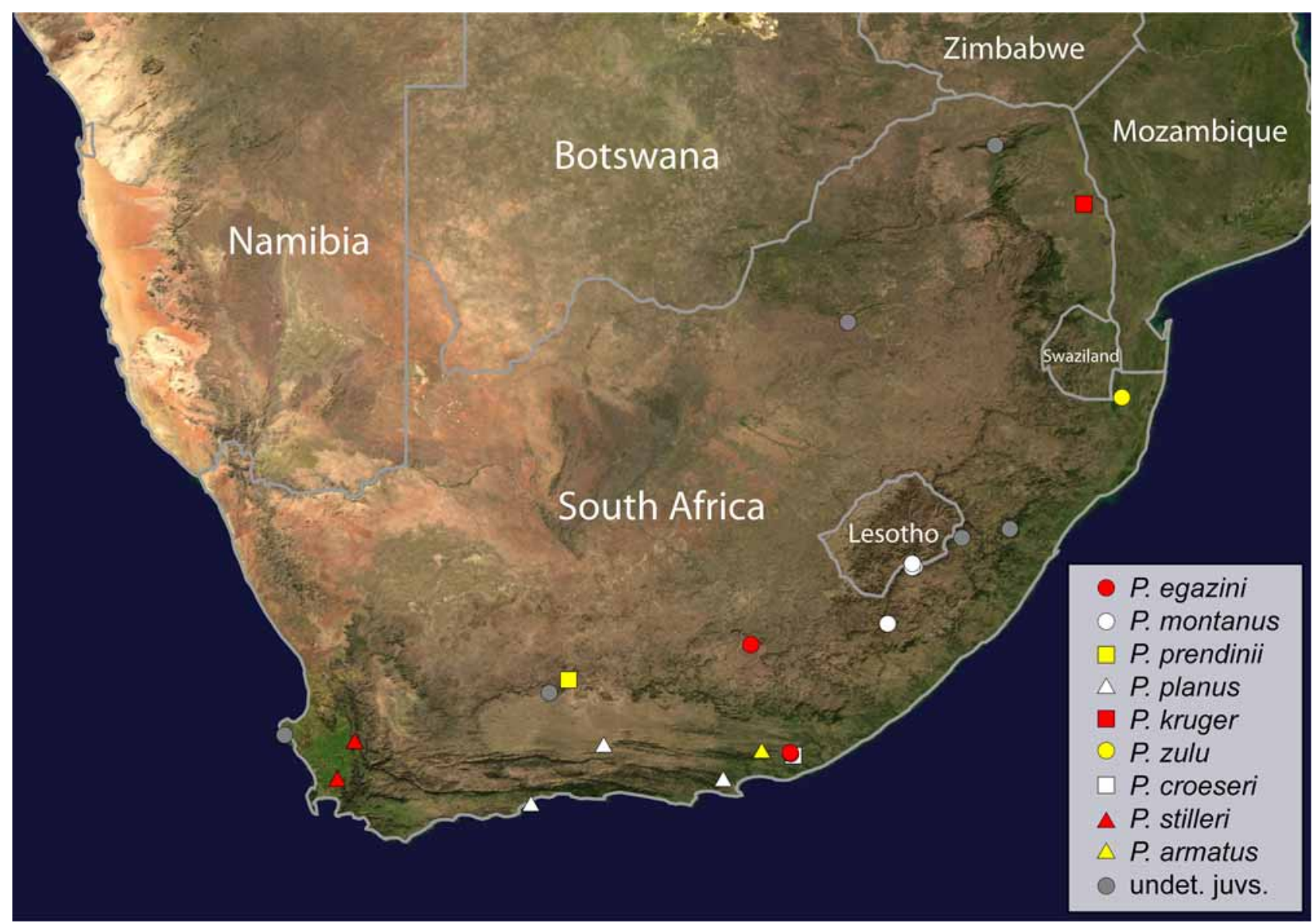

FIGURE 21. Distribution of Penestomus species. Red circle, $P$. egazini sp. nov.; white circle, $P$. montanus sp. nov.; yellow square, $P$. prendinii sp. nov.; white triangle, $P$. planus Simon, 1902; red square, $P$. kruger sp. nov.; yellow circle, $P$. zulu sp. nov.; white square, $P$. croeseri Dippenaar-Schoeman, 1989; red triangle, P. stilleri (Dippenaar-Schoeman, 1989); yellow triangle, P. armatus (Lehtinen, 1967); gray circles, Penestomus from localities represented only by juveniles. To explore distribution data using Google Earth, see supplementary file (http://www.mapress.com/zootaxa/ 2010/data/2520/Penestomidae.kml). 


\section{Additional specimens examined}

The following are unidentified juvenile specimens from unique localities (gray circles, Fig. 21). These may represent additional Penestomus species or range extensions of some of the species treated here. Researchers are encouraged to search for adults from these locations.

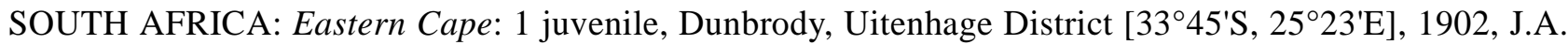

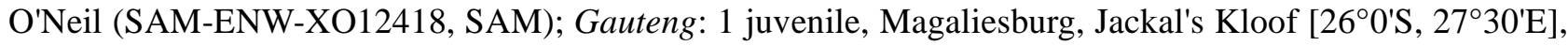
28 March 1999, J. Leeming (AcAT 2000/253, JDL 00106, NCA); KwaZulu Natal: 1 juvenile, Umgeni Valley, nr Howick [29 $30^{\circ}$ S, 30 ${ }^{\circ} 15^{\prime} \mathrm{E}$ ], 2 March 1992, J. Leroy (AcAT 94/628, LR 875, NCA); 1 juvenile, Sani Pass [29.62 $\left.{ }^{\circ} \mathrm{S}, 29.3895^{\circ} \mathrm{E}\right]$, September 2007, pitfall traps, grassland, D. Prentice (AcAT 2008/588, NCA);

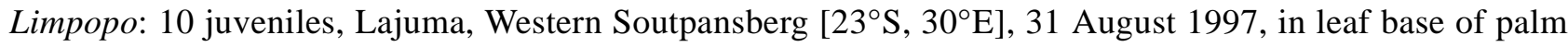
tree, S. Foord (AcAT 2001/296, NCA); Western Cape: 4 juveniles, Karoo National Park [32 $\left.{ }^{\circ} 17^{\prime} \mathrm{S}, 2^{\circ}{ }^{\circ} 26^{\prime} \mathrm{E}\right], 1$ April 1994, on top of mountain, on radio mast, A. Leroy (AcAT 95/318, NCA); 1 juvenile, Karoo National Park, near Beaufort West [32 ${ }^{\circ} 17^{\prime}$ S, $2^{\circ}{ }^{\circ} 6^{\prime} \mathrm{E}$ ], 3 April 1989, web in grass, A. Leroy (AcAT 89/708, LR 369, CAS); 1 juvenile, same data, 6 October 1989, under rock (AcAT 91/358, LR 537, NCA); 1 juvenile, same data, 5 October 1989, under flat rock, B. Schumann (AcAT 91/363, LR 570, NCA); 1 juvenile, Karoo National Park, Puttersvlei [32 $17^{\prime}$ S, $22^{\circ} 26^{\prime}$ E], 3 April 1989, A. Leroy (AcAT 96/246, LR 1184 , NCA); 1

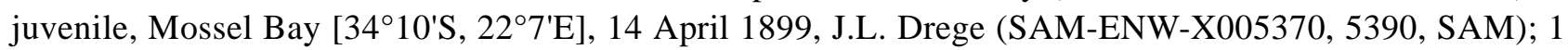

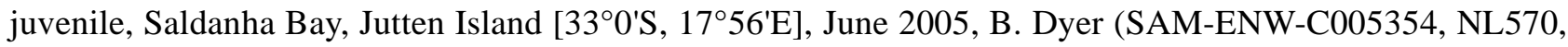
SAM); 1 juvenile, same data (SAM-ENW-C005355, NL571, SAM); 1 juvenile, same data, (SAM-ENWC005356, NL572, SAM).

\section{Acknowledgments}

We thank two anonymous reviewers and editor Michael Rix for their constructive comments on a draft of the manuscript. Giovanni Maki created the illustrations of male genitalia. Joel Ledford contributed several SEM images. Thanks to Hannah Wood for her assistance collecting and maintaining live Penestomus egazini. Norman Larsen shared an excerpt from his unpublished checklist of Cape Town spiders. Thanks to Brian Fisher (CAS) and Norm Penny (CAS) for their help identifying prey remains. Thanks to Deb Paul for help with Morphbank, David Shorthouse for help with LifeDesks, and Katja Schultz and Nathan Wilson for help with Encyclopedia of Life. Cees Hof helped to expose the specimen data on GBIF. Richard Pyle (Bishop Museum) generously facilitated an early account on ZooBank.

We are grateful to the following institutions and individuals for the loan of specimens: Margie Cochrane (SAM), Ansie Dippenaar-Schoeman (NCA), Christine Rollard (MNHN), Peter Schwendinger (MHNG), Lorenzo Prendini (AMNH), and Sarah Gess (AMG).

We would like to thank the California Academy of Sciences for the following support: the Exline-Frizzel Fund for Arachnological Research for general support for all aspects of the project, the Lindsay Travel Fund for support for fieldwork in South Africa by J. Miller and H. Wood, and the Schlinger Foundation Postdoctoral Fellowship in Entomology for support for J. Miller. A grant from the Schlinger Foundation made the illustrations by G. Maki possible. Images provided by J. Ledford were made possible through the support of NSF grant EAR-0228699 (Assembling the Tree of Life: Phylogeny of Spiders) (W. Wheeler P.I.).

\section{References}

Agosti, D. \& Egloff, W. (2009) Taxonomic information exchange and copyright: the Plazi approach. BMC Research Notes, 2, 53. doi:10.1186/1756-0500-2-53.

Arzberger, P., Schroeder, P., Beaulieu, A., Bowker, G., Casey, K., Laaksonen, L., Moorman, D., Uhlir, P. \& Wouters, P. (2004) Promoting access to public research data for scientific, economic, and social development. Data Science 
Journal, 3, 135-152.

Bosselaers, J. \& Jocqué, R. (2000) Studies in Corinnidae: transfer of four genera and description of the female of Lessertina mutica Lawrence 1942. Tropical Zoology, 13, 305-325.

Coddington, J. A. (1983) A temporary slide mount allowing precise manipulation of small structures. Verhandlungen naturwissenschaften vereins Hamburg (NF), 26, 291-292.

Coddington, J. A. (1990) Ontogeny and homology in the male palpus of orb-weaving spiders and their relatives, with comments on phylogeny (Araneoclada: Araneoidea, Deinopoidea). Smithsonian Contributions to Zoology, 496, 152 .

Coddington, J. A. \& Levi, H. W. (1991) Systematics and evolution of spiders (Araneae). Annual Review of Ecology and Systematics, 22, 565-592.

Costello, M. J. (2009) Motivating online publication of data. BioScience, 59, 418-427.

Dippenaar-Schoeman, A. S. (1989) The African species of the subfamily Penestominae (Araneae: Eresidae): with descriptions of two new species. Phytophylactica, 21, 131-134.

Dippenaar-Schoeman, A. S. (2002) Baboon and trapdoor spiders of southern Africa: an identification manual. Plant Protection Research Institute Handbook no. 13. Agricultureal Research Council, Pretoria, 128 pp.

Dippenaar, A. S. \& Meyer, M. E. P. (1980) On the species of the African genus Ammoxenus (Araneae: Ammoxenidae), with decriptions of two new species. Journal of the Entomological Society of South Africa, 43, 41-49.

Eysenbach, G. (2006) Citation advantage of open access articles. PLOS Biology, 4, e157. DOI: 10.1371/ journal.pbio.0040157.

Gallon, R. C. (2002) Revision of the African genera Pterinochilus and Eucratoscelus (Araneae, Theraphosidae, Harpactirinae) with description of two new genera. Bulletin of the British Arachnological Society, 12, $201-232$.

Gewin, V. (2002) All living things, online. Nature, 418, 362-363.

Godfray, C. J., Clark, B. R., Kitching, R. L., Mayo, S. J. \& Scoble, M. J. (2007) The web and the structure of taxonomy. Systematic Biology, 56, 943-955.

Griswold, C. E. (1990) A revision and phylogenetic analysis of the spider subfamily Phyxelidinae (Araneae, Amaurobiidae). Bulletin of the American Museum of Natural History, 196, 1-206.

Griswold, C. E. (1991a) Cladistic biogeography of Afromontane spiders. Australian Systematic Botany, 4, 73-89.

Griswold, C. E. (1991b) A revision and phylogenetic analysis of the spider genus Machadonia Lehtinen (Araneae, Lycosoidea). Entomologica Scandinavica, 22, 305-351.

Griswold, C. E. (1993) Investigations into the phylogeny of lycosoid spiders and their kin (Arachnida: Araneae: Lycosoidea). Smithsonian Contributions to Zoology, 539, 1-39.

Griswold, C. E. (1994) A revision and phylogenetic analysis of the spider genus Phanotea Simon (Araneae, Lycosoidea). Sciences Zoologiques, Musée Royal de l'Afrique Centrale, 273, 1-83.

Griswold, C. E. (2001) A monograph of the living world genera and Afrotropical species of cyatholipid spiders (Araneae, Orbiculariae, Araneoidea, Cyatholipidae). Memoirs of the California Academy of Sciences, 26, 1-251.

Griswold, C. E., Coddington, J. A., Hormiga, G. \& Scharff, N. (1998) Phylogeny of the orb-web building spiders (Araneae, Orbiculariae: Deinopoidea, Araneoidea). Zoological Journal of the Linnean Society, 123, 1-99.

Griswold, C. E., Coddington, J. A., Platnick, N. \& Forster, R. R. (1999) Towards a phylogeny of entelegyne spiders. Journal of Arachnology, 27, 53-63.

Griswold, C. E. \& Platnick, N. I. (1987) On the first African spiders of the family Orsolobidae (Araneae, Dysderoidea). American Museum Novitates, 2892, 1-14.

Griswold, C. E., Ramírez, M., Coddington, J. A. \& Platnick, N. (2005) Atlas of phylogenetic data for entelegyne spiders (Araneae: Araneomorphae: Entelegynae) with comments on their phylogeny. Proceedings of the California Academy of Sciences, 56, 1-324.

Haddad, C. R. (2006) Spinotrachelas, a new genus of tracheline sac spiders from South Africa. African Invertebrates, 47, 85-93.

Haddad, C. R. (2007) A revision of the endemic South African dark sac spider genus Austrophaea Lawrence, 1952 (Araneae: Corinnidae). African Invertebrates, 48, 47-53.

Haddad, C. R. (2009) Vendaphaea, a new dark sac spider genus apparently endemic to the Soutpansberg Mountains, South Africa (Araneae: Corinnidae). African Invertebrates, 50, 269-278.

Haddad, C. R. \& Bosselaers, J. (2010) A revision of the genus Medmassa Simon, 1887 (Araneae: Corinnidae) in the Afrotropical region. Zootaxa, 2361, 1-12.

Haddad, C. R. \& Lyle, R. (2008) Three new genera of tracheline sac spiders from southern Africa (Araneae: Corinnidae). African Invertebrates, 49, 37-76.

Haddad, C. R., Lyle, R., Bosselaers, J. \& Ramírez, M. (2009) A revision of the endemic South African spider genus Austrachelas, with its transfer to the Gallieniellidae (Arachnida: Araneae). Zootaxa, 2296, 1-38.

Holm, А. (1979) A taxonomic study of European and east African species of the genera Pelecopsis and Trichopterna (Araneae, Linyphiidae), with descriptions of a new genus and two new species of Pelecopsis from Kenya. Zoologica Scripta, 8, 255-278. 
House of Lords (2008) Systematics and taxonomy: follow-up. HL Paper No. 162. Her Majesty's Stationary Office (HMSO), London, $330 \mathrm{pp}$.

Jocqué, R. (1991) A generic revision of the spider family Zodariidae (Araneae). Bulletin of the American Museum of Natural History, 201, 1-160.

Jocqué, R. (1999) The new genera Procydrela and Rotundrela, sister taxa for Storenomorphinae and Cydrelinae (Araneae: Zodariidae). Entomologica Scandinavica, 30, 225-240.

Jocqué, R. (2001) Chummidae, a new spider family (Arachnida, Araneae) from South Africa. Zoological Journal of the Linnean Society, 254, 481-493.

Jocqué, R. (2009) Some keep it short: on the radiation in the Afrotropical spider genera Capheris and Systenoplacis (Araneae, Zodariidae) without male pedipalp complexity increase. Journal of Afrotropical Zoology, 5, 77-148.

Lawrence, S. (2001) Free online availability substantially increases a paper's impact. Nature, 411, 521. doi:10.1038/ 35079151.

Lee, M. S. Y. (2000) A worrying systematic decline. Trends in Ecology and Evolution, 15, 346.

Lehtinen, P. T. (1967) Classification of the cribellate spiders and some allied families. Annales Zoologici Fennici, 4 , 199-468.

Miller, J. A., Carmichael, A., Ramírez, M., Spagna, J., Haddad, C. R., Řezáč, M., Johannesen, J., Král, J., Wang, X.-P. \& Griswold, C. E. (2010) Phylogeny of entelegyne spiders: Affinities of the family Penestomidae (NEW RANK), generic phylogeny of Eresidae, and asymmetric rates of change in spinning organ evolution (Araneae, Araneoidea, Entelegynae). Molecular Phylogenetics and Evolution, 55, 786-804. doi:10.1016/j.ympev.2010.02.021.

Penev, L., Erwin, T. L., Miller, J. A., Chavan, V., Moritz, T. \& Griswold, C. E. (2009) Publication and dissemination of datasets in taxonomy: ZooKeys working example. ZooKeys, 11, 1-8.

Platnick, N. I. (2010) The World Spider Catalog, Version 10.5. American Museum of Natural History, Available from http://research.amnh.org/entomology/spiders/catalog/index.html.

Platnick, N. I. \& Griffin, E. (1990) On Rastellus, a new genus of the spider family Ammoxenidae (Araneae, Gnaphosoidea). American Museum Novitates, 2971, 1-16.

Scoble, M. J., Clark, B. R., Godfray, C. J., Kitching, I. J. \& Mayo, S. J. (2007) Revisionary taxonomy in a changing elandscape. Tijdschrift voor entomologie, 150, 305-317.

Shimodaira, H. \& Hasegawa, M. (1999) Multiple comparisons of log-likelihoods with applications to phylogenetic inference. Molecular Biology and Evolution, 16, 1114-1116.

Simon, E. (1902) Descriptions de quelques arachnides nouveaux de la section des cribellatés. Bulletin de la Société entomologique de France, 1902, 240-243.

Simon, E. (1903) Histoire Naturelle des Araignées. Deuxième edition. Volume 2, 669-1080.

Wheeler, Q. D. (2008) The New Taxonomy. The Systematics Association Special Volume Series 76, CRC Press, Boca Raton, $237 \mathrm{pp}$.

Wilson, E. O. (2003) The encyclopedia of life. Trends in Ecology and Evolution, 18, 77-80. 